NBER WORKING PAPER SERIES

\title{
COLLEGE REMEDIATION GOES BACK TO HIGH SCHOOL: EVIDENCE FROM A STATEWIDE PROGRAM IN TENNESSEE
}

\author{
Thomas J. Kane \\ Angela Boatman \\ Whitney Kozakowski \\ Christopher Bennett \\ Rachel Hitch \\ Dana Weisenfeld \\ Working Paper 26133 \\ http://www.nber.org/papers/w26133 \\ NATIONAL BUREAU OF ECONOMIC RESEARCH
1050 Massachusetts Avenue
Cambridge, MA 02138 \\ August 2019
}

We gratefully acknowledge financial support from the Bill \& Melinda Gates Foundation. We thank Mike Krause, Emily House, and Victoria Harpool (from the Tennessee Higher Education Commission), Nate Schwartz, Jonathan Attridge, and Lacey Hartigan (from the Tennessee Department of Education), Robert Denn, Jeannette Tippett, and Abbie Alexander (from the SAILS program), Russ Deaton and Chris Tingle (from the Tennessee Board of Regents), Gregory Kienzl (ACT) and Tammy Lemon (P20 Connect). We received much helpful advice and feedback from our program officers, Yvonne Belanger and Janet Salm, throughout the project, as well as Judy Scott-Clayton who provided detailed comments on an early draft. We also thank Beth Morton for research assistance, Rachel Urso for district and school recruitment, Claire Gogolen for development and administration of the teacher survey, and Jon Fullerton and Corinne Herlihy for feedback on data collection and analysis. Finally, we thank the thousands of students, teachers and principals in the Tennessee high schools that participated in the study. The views expressed herein are those of the authors and do not necessarily reflect the views of the National Bureau of Economic Research.

NBER working papers are circulated for discussion and comment purposes. They have not been peer-reviewed or been subject to the review by the NBER Board of Directors that accompanies official NBER publications.

(C) 2019 by Thomas J. Kane, Angela Boatman, Whitney Kozakowski, Christopher Bennett, Rachel Hitch, and Dana Weisenfeld. All rights reserved. Short sections of text, not to exceed two paragraphs, may be quoted without explicit permission provided that full credit, including () notice, is given to the source. 
College Remediation Goes Back to High School: Evidence from a Statewide Program in Tennessee Thomas J. Kane, Angela Boatman, Whitney Kozakowski, Christopher Bennett, Rachel Hitch, and Dana Weisenfeld

NBER Working Paper No. 26133

August 2019

JEL No. H52,H75,I21,I23,I24,J24

\section{ABSTRACT}

Many U.S. students arrive on college campus lacking the skills expected for college-level work. As state leaders seek to increase postsecondary enrollment and completion, public colleges have sought to lessen the delays created by remedial course requirements. Tennessee has taken a novel approach by allowing students to complete their remediation requirements in high school. Using both a difference-in-differences and a regression discontinuity design, we evaluate the program's impact on college enrollment and credit accumulation, finding that the program boosted enrollment in college-level math during the first year of college and allowed students to earn a modest 4.5 additional college credits by their second year. We also report the first causal evidence on remediation's impact on students' math skills, finding that the program did not improve students' math achievement, nor boost students' chances of passing college math. Our findings cast doubt on the effectiveness of the current model of remediation-whether in high school or college-in improving students' math skills. They also suggest that the time cost of remediation-whether pre-requisite or co-requisite remediation-is not the primary barrier causing low degree completion for students with weak math preparation.

Thomas J. Kane

Harvard Graduate School of Education

Center for Education Policy Research

50 Church St., 4th Floor

Cambridge, MA 02138

and NBER

kaneto@gse.harvard.edu

Angela Boatman

Department of Educational Leadership

and Higher Education

Boston College

222 Campion Hall

Chestnut Hill, MA 02467

USA

angela.boatman@bc.edu

Whitney Kozakowski

Harvard Graduate School of Education

Cambridge, MA 02138

wkozakowski@g.harvard.edu
Christopher Bennett

Vanderbilt University

230 Appleton Place

PMB 414

Nashville, TN 37203

chris.bennett@vanderbilt.edu

Rachel Hitch

Center for Education Policy Research

50 Church Street, 4th Floor

Cambridge, MA 02138

griffish@gse.harvard.edu

Dana Weisenfeld

Center for Education Policy Research

50 Church Street, 4th Floor

Cambridge, MA 02138

dana_weisenfeld@gse.harvard.edu 


\section{INTRODUCTION}

Given the large wage differences between high-school and college-educated labor, governors in 42 states have set ambitious goals for increasing postsecondary attainment for their residents by 2025 (Lumina Foundation, 2018.) To meet such targets, state leaders must find ways to serve the large numbers of students arriving at college without the math and literacy skills traditionally expected for college-level coursework. Among first- and second-year college students nationally in 2011-12, 29 percent of students at public 4-year institutions and 41 percent of those at public 2-year institutions reported taking at least one remedial course (Skomsvold, 2014).

Given the high proportion of remedial students who never complete any degree, advocacy organizations, such as Complete College America, have argued that remedial requirements are an unnecessary barrier and a cause of non-completion, describing college-level remediation as a "bridge to nowhere" (Complete College America, 2012). As a result, postsecondary institutions in many states have been reducing the time and delay created by remediation requirements (for instance, by allowing students to take remedial coursework simultaneously with college courses.) Tennessee has taken a unique approach, adjusting both high school curricula and postsecondary remediation requirements.

In 2012, the state launched a pilot initiative, known as the Seamless Alignment and Integrated Learning Support (SAILS) program. The goal of the program was to shift the locus of math remediation from college back to high school. Unlike most states in which students learn of their remediation status only after arriving at college and taking a placement test, Tennessee notifies students of their remediation status in high school based on their junior year ACT score. Students in SAILS-participating high schools who score below the remediation threshold of 19 
on the ACT math test (roughly half of the seniors in those schools) can fulfill their math remediation by completing an online, in-person math course during their senior year. Although staffed by high school instructors, the course is modelled on the remedial course offered in community colleges in Tennessee. Those who complete all five modules are exempted from math remediation when they enroll at a Tennessee community college.

Beyond assessing the results of Tennessee's unique approach to the remediation challenge, we make three additional contributions to the research on remediation:

First, we present a simple framework for interpreting the effect of remediation requirements: the "achievement effect" and the "delay/displacement effect". Remedial courses may boost students' understanding of math and allow them to make faster progress in subsequent courses requiring such skills ("the achievement effect"), but at the cost of delaying or displacing college-level courses (the "delay/displacement" effect.) By describing prior estimates as the sum of two parts, we hope to resolve the apparent contradiction between the prior findings of small negative effects of remediation and recent claims that remediation is a primary cause of high drop-out rates. Both could be true, but only if both achievement and the delay/displacement effects were large. The design of the Tennessee program allows us to estimate both separately.

Second, we measure impacts of remedial coursework on math achievement using a regression discontinuity design. Past research has overlooked such achievement impacts due to lack of data on the counter-factual: while most students are assigned to remediation based on a single test score, they complete remediation by passing the remedial course. Colleges rarely collect posttest data for participants, and even less often do they gather such data for a comparison group. Thus, in order to learn about the impact of SAILS, we administered a posttest and student survey to high school seniors in 119 schools participating in the SAILS 
program. Using an RD design, we compare the subsequent achievement and survey responses of high school seniors who scored just above and below the threshold as juniors.

Third, we measure the opportunity cost of remedial requirements under both pre-requisite remediation (the "delay effect") and co-requisite remediation (the "displacement effect.") Prior to 2015, Tennessee community colleges required students who had not completed SAILS to pass their remedial coursework before enrolling in college-level courses ("pre-requisite remediation"); for the seniors of 2014-15 and 2015-16, Tennessee community colleges allowed students to do their remediation as a co- requisite, taking remedial courses alongside college-level courses. Corequisite remediation has been seen as an increasingly popular alternative to high-school based remediation such as SAILS, with several states such as Florida, California and Texas moving to statewide adoption (Logue, Douglas, Watanabe-Rose, 2019). Although not imposing the same delay created by pre-requisite remediation, co-requisite requirements may still crowd-out or displace college level coursework, given constraints on students' time. Depending on the year in which a high school first began implementing the program, SAILS allowed students to avoid either pre-requisite or co-requisite remediation. We measure both the "delay effect" of prerequisite remediation and the "displacement effect" of co-requisite remediation using a difference-in-difference design, comparing the changes in student outcomes for high schools implementing SAILS in different years. Since co-requisite remediation and high-school remediation are viewed as alternative ways of achieving similar goals, the incremental effect of SAILS once the co-requisite policy was in place is relevant to current policy discussions. We find that, under the pre-requisite policy, remediation-eligible students (i.e. those with ACT math scores below 19) enrolled in college-level math at higher rates after their high schools began implementing SAILS, resulting in a 13-percentage point increase in the percentage of 
students having passed college math by the end of their first year. By the end of their second year in college, SAILS participants completed 4.5 additional college credits (roughly 1.5 courses) compared to their counterparts in high schools without SAILS. ${ }^{1}$ In other words, students were able to complete an additional college level course in place of the remedial math course that was waived. However, removing the delay of the remedial course did not lead to a burst of progress beyond that course. In other words, it does not seem that remediation requirements were the primary constraint getting in the way of college credit accumulation for students.

Second, SAILS appeared to improve students' perceptions of the usefulness and enjoyment of math. Students just below the ACT math cutoff of 19 were more likely to perceive that their math course content would be useful in their careers, to indicate they were better prepared for college math, and to say that they were interested in math than those immediately above the remediation threshold.

Third, despite the positive impacts on students' perceptions of math, there was no difference in math performance on the posttest for those immediately above and below the remediation threshold (although the latter often took the SAILS course and the former did not), implying that the course had little impact on students' math achievement over and above the high school math course they would have taken otherwise.

Finally, after the co-requisite policy was introduced in the fall of 2015, SAILS no longer had an impact on the percentage of students taking or passing college math during their first year, nor on the total number of credits completed at the end of their second year. The co-requisite policy largely superseded the SAILS program by allowing students to complete their remediation alongside college-level courses, rather than before them. Once the co-requisite policy was in

\footnotetext{
${ }^{1}$ Our measure of college credits earned excludes those earned prior to high school graduation (e.g., dual enrollment).
} 
place, exempting students from co-requisite courses did not allow students to make any faster progress toward their degrees.

However, SAILS and the co-requisite policy were not perfect substitutes. Even without additional impacts on credit accumulation, the SAILS model has an important advantage over the co-requisite policy: the SAILS program allowed a quarter of remediation-eligible students to fulfill their remedial requirements in high school, rather than wait to do so in college. Because high school seniors in Tennessee are required to take four years of math, such a shift represented a net cost savings for students and taxpayers (given that the pupil to teacher ratio in the SAILs course was similar to other high school math courses.)

In sum, either approach to replacing pre-requisite remediation-- moving remediation to high school or allowing students to do math remediation as a co-requisite-- seems to allow community college students to enroll in college math more quickly and to accumulate an additional 1.5 college courses by the end of their second year. However, such findings also suggest that the pre-requisite remediation requirement is not the primary barrier to credit accumulation and degree completion for many students - since, if it were, we would have expected a larger burst of credit accumulation than the single course. Moreover, the SAILS program did not seem to increase students' math achievement. Because the SAILS course was modelled on the course delivered in community colleges, our findings raise doubts about the impact of those courses in remediating students' math skills as well. We close by discussing the promise of alleviating other potential barriers to college completion, such as better college advising and efforts to remediate math skills earlier in high school. 


\section{LITERATURE REVIEW AND THEORETICAL FRAMEWORK}

In theory, remedial course requirements produce two types of effects: 1) they refresh students' content knowledge in math (the "achievement effect"), and 2) they delay (in the case of pre-requisite remediation) or displace (in the case of co-requisite remediation) students' ability to accumulate degree credits during their initial years in college (the "delay/displacement effect").

The achievement effect and the delay/displacement effects could partially—or fully— offset each other. The remedial course may accelerate students' progress in subsequent collegelevel courses. However, the time required to take the remedial course also diverts a student from accumulating college-level credits for a degree. The former is hopefully positive, the latter negative. The net effect of any remediation policy depends on the sum of the two effects.

Unfortunately, researchers have been unable to distinguish between the achievement and delay/displacement effects, focusing instead on the net effect of being flagged for remediation. For instance, Calcagno and Long (2008) compared community college entrants on either side of the remediation threshold in Florida. While they found a small positive effect of being recommended for remediation on persistence after the first year of college, they ultimately found no differences in degree completion, transfer, or completion of college credits. Martorell and McFarlin (2011) studied over 250,000 students in public two-and 4-year colleges in Texas and found that being identified for remediation slightly reduced credit accumulation and years in college, but had no impact on degree attainment. Scott-Clayton and Rodriguez (2015) found that students recommended for remediation in a large, urban community college system were no less likely to enroll in postsecondary education or earn a college degree and completed roughly the same numberof terms and college credits as those immediately above the cutoff. Using data from Tennessee, Boatman and Long (2018) found that in the years before the SAILS program students 
on the margins of needing one developmental math course were less likely to persist to the second year in college, and 5 percentage points less likely to have completed a degree within eight years.

Two recent studies have examined the effects of remedial interventions offered earlyeither in the summer or during a first semester. Early Start, adopted in 2012 in California, requires incoming California State University students to complete their remedial math and/or English requirements in the summer prior to beginning college. Using an RD approach, Kurlaender, Lusher, and Case (2017) found no significant improvements in persistence or firstterm GPA for students identified as needing math remediation under Early Start. The second study focused on the City University of New York's (CUNY) Start program, which launched in 2009. The program delays college enrollment for one semester for incoming students who are assessed as needing remediation in math, reading, and writing, and instead provides intensive instruction in math, reading, and writing during that semester. It also provides a number of services that go beyond remediation: providing advising, tutoring, and study skills courses. In a randomized experiment, eligible students were assigned to CUNY Start or to traditional remedial courses. Early results indicate that the program leads students to remain enrolled in CUNY colleges at higher rates during the second semester (Scrivener et al., 2018). The authors also examined the effects on student learning. They found that the treatment group had higher performance in math, reading and writing. However, given substantial differential attrition in the treatment and control groups, it is impossible to know if the treatment caused the improvement or if the estimated effect was driven by differences in the composition of test-takers in the two groups (e.g., the students who did not improve were less likely to take the test, especially in the treatment group.) Given these limitations, the authors describe their results as "suggestive." 
Nationally, only 34 percent of community college students who enroll in a remedial course complete a degree within six years (BPS, 2009). Such statistics have led critics of remediation requirements to claim that the relationship is a causal one-that remediation requirements delay students needlessly and lead many students to drop out (i.e. remediation is a "bridge to nowhere.") However, given that the previous research on the impacts of college remediation suggests that being recommended for remediation has a moderately negative or null effect on degree completion, there are only two possible hypotheses that would be consistent with small net effects:

First, remedial course requirements may generate delays for many students, but since the net effect is small, itwould also have to be the case that remedial courses allow students to make substantially faster progress toward a degree (the "high delay/high achievement boost" hypothesis.) Therefore, moving the remediation to high school and eliminating the delays caused by remedial coursework in college would be expected to generate a large boost in postsecondary attainment.

Alternatively, it could be that both the achievement effect and the delay effects of remediation are small (the "low delay/low achievement boost" hypothesis.) (Other possibilities, such as the hypothesis that remediation is both costly in terms of time and unhelpful in terms of achievement would not be consistent with the prior literature, because we would have expected large negative net effects of being flagged for remediation.)

Because the SAILS high school course is modelled on the remedial math course offered in community colleges, the SAILS program essentially provides the achievement boost of remediation, without the time cost in college. Thus, we first measure the impact on remediationeligible students when their high schools began offering SAILS under pre-requisite remediation. 
Under the high delay/high achievement boost hypothesis, we would have expected to see a large increase in college math enrollments, math completion and credit accumulation after schools began implementing SAILS.

Later, when public colleges in Tennessee adopted the co-requisite policy, we measure the displacement effect of co-requisite remediation courses. Again, if the displacement effect of corequisite remediation requirements at community college were large, we would expect to see a large increase in credit accumulation for students at the schools implementing SAILS for the first time.

In addition to measuring the effect of SAILS in reducing the delay/displacement involved in college-level remediation, we also measure the impacts of SAILS on students' math achievement by comparing achievement on a posttest for those immediately above and below the cutoff for remediation. If the high delay/high achievement boost hypothesis were true, and there was a large achievement boost from remediation, we would expect to see a large impact from participating in SAILS on students' math achievement.

\section{STATE CONTEXT}

In the fall of 2012, 68 percent of first-year, first-time community college students in Tennessee were enrolled in one or more developmental or remedial courses (Tennessee Higher Education Commission, 2014). For first-time, full-time students who entered Tennessee community colleges in fall 2011, only 28 percent completed a credential within 6 years (Tennessee Higher Education Commission, 2018). As in many states, the high rates of remediation and the low rates of degree and certificate completion have led leaders in Tennessee to see remediation requirements as a primary barrier to degree completion. 
Unlike most other states, Tennessee notifies students of their remediation status in high school. Tennessee uses students' 11th grade ACT math test scores to assign students to remedial courses. The vast majority of students (around 82 percent each year) take the ACT in school during their junior year. Students scoring below 19 on the ACT math test are told that they will need to take a remedial course in math if they enroll in a public college or university in Tennessee. Students who complete the SAILS curriculum in high school can avoid that requirement if they proceed to enroll in a Tennessee community college.

\section{Tennessee SAILS Program}

The SAILS course is self-paced, with students progressing through the material on their own schedule, either over one semester or across the whole school year depending on their school's course schedule. The course material is delivered entirely online, including videos, homework problems, and assessments. Most of the work is completed in class, although students have the option of working outside of class as well. Teachers serve as learning partners and coaches; although they occasionally provide direct instruction, their primary role is to monitor students' progress through the online modules and provide guidance when students are stuck. Students and teachers are assisted by a team of field coordinators distributed across the 13 community colleges and overseen by the Tennessee Board of Regents. Of the students who enrolled in the SAILS course in 2015-16, the vast majority (92 percent) completed the course successfully. Completion rates were similar in 2014-15 but were lower in 2013-14 (69 percent) (Higher Education for Higher Standards, 2016).

The program was rolled out to 20 high schools in 2012-13. With additional state support, the program expanded each year, serving 122 high schools in 2013-14, 182 high schools in 201415, and 243 high schools in 2015-16. Beginning in 2012, students in Tennessee high schools 
were required to enroll in math during all four years of high school in order to receive their diploma.Therefore, for students enrolled in SAILS, the course is substituting for another high school math course such as Pre-Calculus, Statistics, and Advanced Algebra and Trigonometry, or Bridge Math. Bridge Math covers similar remedial math concepts as SAILS, although it is taught in a traditional, direct-instruction format. A key difference is that students who successfully complete Bridge Math courses do not receive automatic exemption from math remediation in Tennessee community colleges. Although Bridge Math continues to be taught in SAILSparticipating high schools, our results below suggest that SAILS participants are not being drawn other senior math courses such as Advanced Algebra and Trigonometry and Statistics. ${ }^{2}$

\section{The Tennessee Promise and Co-Requisite Remediation}

As the SAILS program was expanding, Tennessee became the first state in the country to offer statewide, tuition-free community college education for recent high school graduates (beginning with the high school class of 2014-15). The Tennessee Promise scholarship covers the cost of tuition and fees for recent high school graduates attending community and technical colleges, along with a small number of public and private 4-year institutions offering associate degrees. It is a "last dollar" scholarship, covering the cost of tuition and required fees that remain after subtracting grant aid from other sources (e.g., Pell Grant, Tennessee HOPE scholarship). There are no minimum ACT or high school GPA eligibility requirements for the Tennessee Promise. Approximately three quarters of first-time freshman at Tennessee community colleges received the TN Promise in 2014-15 (Tennessee Higher Education Commission \& Student Assistance Corporation, 2018).

\footnotetext{
${ }^{2}$ As reported in Table 4, there was no statistically significant difference in Bridge Math enrollments at the remediation threshold in the SAILS participating schools.
} 
Also in fall 2015, Tennessee's community colleges transitioned from a policy of prerequisite remediation to a co-requisite policy, in which students are required to enroll in a remedial course simultaneously with their college-level course. Like SAILS, the new remediation policy was intended to allow students to enroll in college-level coursework directly (Tennessee Board of Regents, 2016). However, a key difference is that SAILS allows students to avoid having to take the remedial class entirely, potentially freeing up time to take other classes, while the co-requisite remedial classes may have crowded out course-taking for other students.

Because the Tennessee Promise and the co-requisite policy were implemented at the same time, it is not possible for us to isolate the independent effect of each. However, it seems that the combination of policy changes did have substantial impact. Figure 1 presents the proportion of students enrolling in postsecondary education for the high school seniors of 2010-11 through 2015-16. We report trends separately for those with ACT math scores below 19 (the remediationeligible) and for those with ACT math scores of 19 and above. We also report separately for the institutions that were and were not eligible forTennessee Promise scholarships. ${ }^{3}$ There was more than a 10-point increase in the percentage of remediation-eligible students enrolling in institutions eligible for the Tennessee Promise. There was a smaller increase in college entry among those with ACT math scores of 19 and above. These increases were accompanied by a small decline in entry at institutions not eligible for the scholarship.

Figure 2 portrays the trend in the proportion of community college entrants taking and passing college math during their first year as well as the average number of college credits students completed by the end of their second year after high school. As in Figure 1, we report the trends separately for those with junior year ACT scores above and below the remediation

\footnotetext{
${ }^{3}$ Eligible institutions included Tennessee community colleges, Tennessee Colleges of Applied Technology, and some 4-year colleges with associate degree programs
} 
threshold of 19. When the co-requisite was implemented, there was a substantial (33-point) increase in the percentage of remediation-eligible students taking college math. It was accompanied by a smaller increase - 15 percentage points - in the proportion of community college entrants passing college math, implying that about half of the new entrants passed the college-level course.

\section{DATA AND SAMPLE}

The Tennessee Department of Education (TDOE) provided K-12 administrative records, including student enrollment, demographic characteristics, courses, and ACT scores on a 1-36 scale for all high school seniors in the 2010-11 through 2015-16 school years. We supplemented the TDOE data with information on the characteristics of students' high schools, such as urbanicity and the proportion of students eligible for free or reduced-price lunch, from the Common Core of Data (CCD). ${ }^{4}$ The Tennessee Higher Education Commission (THEC) and Tennessee Board of Regents (TBR) provided data on students' postsecondary enrollment and community college course grades from 2010-11 through 2016-17, as well as college degree completion from 2010-11 through 2015-16. ACT provided data for the ACT math test scores taken in students' junior year for the graduating high school class of 2015-16. Finally, we received information on student and school participation from the SAILS program itself.

In addition, we administered a posttest and survey to a sample of approximately 16,000 high school seniors at 119 high schools that were implementing SAILS in 2015-16, excluding high schools that were in their first year of SAILS. We focused our data collection for the posttest and survey on students enrolled in certain senior year math classes: all Bridge Math and

\footnotetext{
${ }^{4}$ If a student attended more than one high school during their senior year, we used the school where they attended more days.
} 
SAILS classes, as well as all Advanced Algebra and Trigonometry, Pre-Calculus, and Statistics classes. To lessen the burden on schools, we excluded students in advanced classes such as Advanced Placement and International Baccalaureate classes, since these students were likely to be far above the cut-off. For the posttest, we also excluded students taking geometry in their senior year, as these students typically were scoring far below the threshold. ${ }^{5}$ Among students in the targeted classes, we received posttest and survey results for 69 percent of students, or approximately 11,000 students. Excluding students without valid answer sheets and those for whom ACT and MeasureTN were unable to find a match, we collected responses from approximately 61 percent of students in targeted classes.

The 50-minute, 35-item posttest was an abbreviated version of the ACT math test.

Students took the assessment at the end of their senior year math course either in November 2015 (for fall semester courses) or April 2016 (for spring semester or full-year courses). The posttest was scored by ACT and matched to students' prior ACT records and $\mathrm{K}-12$ records from TDOE. The new scale, which ranged from 333 to 680 , provided a finer level of detail than the integer scale ACT uses for public reporting, which allowed us to identify students within a fraction of a point above and below the remediation cutoff of 19. In addition, during the last five minutes of the posttest, students completed a 15 -item student survey on topics such as perceptions of their math courses, attitudes towards math, and postsecondary aspirations.

\footnotetext{
${ }^{5}$ We also included classes labeled Finite Math, Discrete Math, Core Mathematics, and Algebra II when we saw large numbers of seniors enrolled. However, other courses, particularly junior year courses with less than three seniors enrolled, were also excluded to alleviate the burden of in-class testing for these teachers.
} 


\section{Sample}

Table 1 presents the characteristics of 2015-16 seniors, by the year in which their high school began offering the SAILS program. Because the SAILS program records were incomplete for the 20 schools which implemented the program in 2012-13, we excluded those schools from all years. The 101 high schools which began implementing SAILS in 2013-14 had somewhat higher percentages of White students, fewer Black students, and higher high school graduation rates for seniors than schools that implemented SAILS in the two subsequent years. However, the three waves of high schools each had similar proportions of students scoring below the remediation threshold of 19 (50, 53 and 49 percent respectively). Relative to the schools that had never offered the SAILS program as of 2015-16, the SAILS schools were more likely to be rural (36 vs. 17 percent), more likely to have students with ACT math scores below 19 (51 vs. 46 percent), and more likely to have a higher share of White students (75 vs. 65 percent).

Table 2 compares the student characteristics of the sample to the underlying population at each phase of sample selection. Column 1 describes the characteristics of all students in all eligible schools in their second or third year of implementation in 2015-16. Column 2 reports the characteristics of all students in the subset of schools that agreed to participate. The participating schools were very similar to the eligible schools in most measures, including demographic characteristics and test scores. Column 3 reports the characteristics of all students in the targeted math classes in the participating schools. Students in the targeted classes tended to have lower than average ACT scores, with 63 percent scoring below 19 compared to 54 percent in the full sample. They were also more likely to participate in SAILS than the full population of students in the participating schools (43 vs. 33 percent). ${ }^{6}$ Column 4 reports the characteristics of the

\footnotetext{
${ }^{6}$ They were also more likely to take senior year math (99 percent vs. 92 percent) and were more likely to graduate conditional on beginning their senior year (96 percent vs. 93 percent).
} 
students in the targeted classes for whom we have posttest outcomes. The sample with posttest scores was similar to those in the targeted classes, with the exception that they have slightly fewer days absent and are more likely to graduate. Students who dropped out during their senior year or who were frequently absent may not have been present to take the test.

\section{EMPIRICAL STRATEGY}

We use two different quasi-experimental approaches to measure the impact of the SAILS program. First, we exploit the fact that SAILS was implemented in waves, with high schools implementing the program in different years. For this analysis, we use a difference-in-differences (DD) design, comparing the change in outcomes in schools in the year they began implementing SAILS against the change for those that had not yet implemented or had implemented SAILS in some prior year. Second, we use a RD design that exploits the assignment rule for remediation in Tennessee: scoring below 19 on the ACT math test. In this analysis, we identify the impact of being assigned to remediation of any kind (SAILS, co-requisite and pre-requisite) versus no remediation by comparing students scoring just above the cutoff to those scoring just below the cutoff for assignment to remediation.

\section{Difference-in-Differences (DD) Design}

Using the sample of students who are recommended for remediation, we compare the change in outcomes for students from high schools that implemented SAILS in a given year against the change in outcomes for schools that had not yet implemented SAILS (or had implemented it in a prior year.) The co-requisite policy was implemented in the fall of 2015, affecting the high school graduating classes of 2014-15 and beyond. Therefore, by using the cohort of students who graduated in 2013-14, we can estimate the effect of the SAILS program in the 
context of pre-requisite remediation. We use those graduating in 2014-15 and 2015-16 to estimate the effect of the SAILS program in the context of co-requisite remediation. Specifically, we estimate the following difference-in-differences model:

(1) $Y_{i s t}=\beta_{0}+\beta_{1}$ SAILS_HS_Trad ${ }_{s t}+\beta_{2}$ SAILS_HS_CoReq $q_{s t}+\gamma_{s}+\psi_{t}+\boldsymbol{X}_{i s} \boldsymbol{\alpha}+\epsilon_{i s t}$

In equation (1), $Y_{i s t}$ is an outcome for student $\mathrm{i}$ in high school $\mathrm{s}$ in year $\mathrm{t}$.

SAILS_HS_Trad st $_{\text {e }}$ equals one for high schools implementing SAILS in 2013-14, when the prerequisite policy was in force. SAILS_HS_CoReq $q_{s t}$ equals one for all high schools adopting SAILS in 2014-15 or 2015-16, after the co-requisite policy was adopted. $\gamma_{s}$ and $\psi_{t}$ are high school and year fixed effects respectively. $\boldsymbol{X}_{i s}$ is a vector of time-invariant student demographic characteristics. $\epsilon_{i s t}$ is a stochastic error term. Standard errors are clustered at the high school level. The sample is limited to 12 th grade students who are flagged as needing remediation based on whether they score below 19 on their first junior year ACT score.

The key assumption underlying the DD strategy is that the year-to-year change in SAILSparticipating and non-participating schools would have been the same if not for the implementation of SAILS. One common test of this assumption is to evaluate whether the schools that adopted SAILS were already on a different trajectory prior to adoption. Appendix Table A2 shows that for the majority of outcomes, the trends for SAILS and non-SAILS schools were parallel in the lead-up to the adoption of SAILS.

We also test whether there is any evidence that the composition of the student body is changing with the introduction of SAILS. As reported in Appendix Table A3, we find no 
evidence that the proportion of students who are female, Black, Hispanic, or white changes with the introduction of SAILS relative to the change in non-SAILS schools.

\section{Regression Discontinuity (RD) Design}

In addition, we estimate the following model to compare the outcomes of students just above and just below the remediation cutoff of 19 :

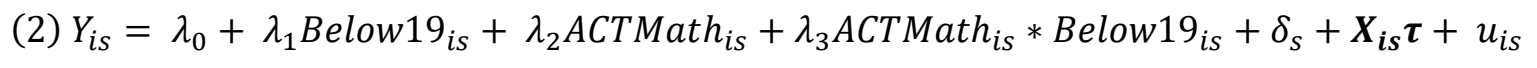

In this model, $Y_{i s}$ represents the outcome for a student $\mathrm{i}$ in school s. Below $19_{\text {is }}$ is an indicator for student $\mathrm{i}$ in school s having an ACT math score below 19. ACTMath is $_{\text {represents a }}$ student's junior year ACT math score (centered at the cutoff) and serves as the running variable. For the class of 2015-16, we have a rescaled version of the ACT with a finer scale than the 1-36 scale used for public reporting (see Figure 4). For 2013-14, we have only the publicly reported 136 scale. $\delta_{s}$ are high school fixed effects, and $\boldsymbol{X}_{\boldsymbol{i}}$ denotes a vector of student-level demographic controls for race and gender. $u_{i s}$ is the idiosyncratic error term. In this model, the parameter of interest is $\lambda_{1}$ which captures any discontinuous shift in the expected value of $Y_{i s}$ at the threshold. We cluster errors at the level of the high school. The main specifications use a bandwidth of $+/-$ 25 points with the finer grained, rescaled ACT scores or $+/-4$ points with the coarse ACT. (In Appendix Tables A4-A8, we show sensitivity tests for wider and narrower bandwidths.)

Because the students most eager to avoid remediation could retake the ACT, we use a student's first ACT math score as the running variable. Following McCrary (2008), we check that the density of students is smooth through the cutoff for each of the subsamples we use for our estimates in Appendix Figures A1 and A2. We also test for balance in the covariates near the 
threshold. In Appendix Tables A4, A5, and A7, we see that student characteristics are generally smooth through the cutoff for the samples that we use for the analyses. The few differences that we observe at the .05 level are consistent with the number of false positives that we would expect when testing this many hypotheses. Moreover, we control for these demographic characteristics in our main estimates and find that the results are not sensitive to their inclusion.

\section{RESULTS}

In Table 3, we estimate the effect of SAILS by examining the change in student outcomes for remediation-recommended students when their high school began using SAILS. To provide some perspective in interpreting the magnitude of the impacts, we also report the mean outcomes for the comparison students (those who had an ACT math score below 19 in high schools that were not participating in SAILS).

In the top panel, we report impacts on outcomes which apply to all high school seniors, whether or not they enter postsecondary education. As reported in the top row, when a high school began implementing SAILS, about 40 percent of remediation-recommended students enrolled in SAILS. Our interviews with school staff suggested that individual student enrollment decisions were based on a number of factors-including student's college aspirations or comfort with technology. In some cases, schools did not have enough qualified teachers or a sufficient number of computers to accommodate all eligible students (IMPAQ International, 2016). Because we may not the various ways that students might be selected into SAILS, we measure the effect of SAILS implementation on all students with scores below the threshold (that is, the results in Table 3 are intent-to-treat estimates.)

As reported in the remaining rows in the top panel, SAILS implementation was not accompanied by any increase in high school graduation, postsecondary enrollment, or a change in 
the type of postsecondary institution attended. Although not surprising given the program goals, the finding suggests that there was not a significant change in the unmeasured characteristics of college entrants.

In the lower panel of Table 3, we report impacts for students who entered community college within one year after graduating from high school. A school's implementation of SAILS was accompanied by a 28-percentage point decline in the percentage of community college entrants taking remedial math during their first year in college. In other words, SAILS implementation succeeded in shifting the locus of remediation from college back to high school for 28 percent of remediation-recommended community college students. The impact was similar under the pre-requisite and co-requisite policies. ${ }^{7}$

In the final rows in Table 3, we report impacts on the proportion of students taking and passing college math during their first and second years in community college. Under the prerequisite policy, SAILS implementation was accompanied by a 14-point boost in the percentage of remediation-recommended students taking college math during their first year, relative to 45 percent in the non-participating schools. After accounting for failures and withdrawals, there was a 6.3-point boost in the percentage of remediation-recommended students passing college math by the end of their first year in college, relative to 30 percent in non-participating schools. In other words, we estimate that SAILS-implementation led to a 14-percentage point increase in college math enrollment. A subset of these students — about 6.3 percentage points — passed

\footnotetext{
${ }^{7}$ To help explain why there was not a 100 percent reduction in college remediation among students attending SAILS high schools, first, only about 40 percent of remediation-recommended students at participating high schools enrolled in SAILS. Second, only 66 percent of students at non-participating high schools with ACT math scores below 19 actually took remedial math in their first year of college. To avoid remediation, these students may have retaken the ACT, taken the ACCUPLACER test once on campus, enrolled in anon-degree program, or delayed taking remedial requirements to later years. The product of these two percentages ( 40 percent $\mathrm{x} 66$ percent $=27$ percent) is similar to the estimated reduction in remediation in Table 3 (28 percent).
} 
college math. The ratio (6.3/14) implies that just under half of the new enrollees in college math passed the course.

The estimated impacts on the percentage of students taking and passing college math were smaller by the end of the second year in college, as students from the non-participating high schools had the opportunity to complete their remedial courses and enroll in college-level classes. By the end of the second year, the estimated impact on the percentage of students passing college math was still positive ( 2 percentage points), but it was no longer statistically significant.

We estimate that SAILS implementation under the pre-requisite policy also resulted in a small increase in the number of college credits students completed: 1.0 credit during the first year and 2.2 credits by the end of the second year. Only 4 percent of remediation-recommended community college entrants completed an associate degree within 2 years. An additional 4 percent of remediation-recommended students completed a certificate program. We saw no statistically significant impact of SAILS implementation either on the proportion of students completing an associate degree or completing a certificate within 2 years. ${ }^{8}$

If we are willing to assume that SAILS had no effect on the outcomes of remediationeligible students who did not participate, we can infer the effect of the SAILS treatment on participating students by dividing the average impact on each outcome by the participation rate. For example, the 14-point increase in the percentage of remediation-recommended seniors taking college math in their first year translates to a 29-percentage point increase in math enrollments for SAILS participants. The 6.6-point increase in the percentage of students passing college math translates to a 13-point increase in the percentage of SAILS participants passing college math. The 2.2 credit increase in credits by the end of the second year translates to a 4.5 credit increase

\footnotetext{
${ }^{8}$ However, some students may not have been seeking an associate degree or certificate, and two years is shorter than the length of time many students require to complete.
} 
for SAILS participants. These are all similar in magnitude to the improvements we reported in Figure 2 between 2013-14 and 2014-15, when community colleges moved to the co-requisite policy and allowed students with ACT scores below 19 to enroll directly in college-level math. ${ }^{9}$

Table 3 also reports the impacts of SAILS implementation for the high school seniors of 2014-15 and 2015-16, after the co-requisite policy was in place. As reported in the top panel, there was a similar shift in the locus of remediation from college back to high school, as the students from SAILS participating high schools were 28 percentage points less likely to enroll in college remediation during their first year in college. However, we no longer estimate a positive impact on the proportion of students taking or passing college math during their first year. In fact, the estimates are negative. Likewise, the estimated impacts on college credits completed by the end of the first and second year of college is not significantly different from zero.

The negative effect on taking college math appears to be driven by the high schools launching SAILS in 2014-15. As shown in Figure 3, the trend in college math course-taking for the set of high schools that implemented SAILS for the first time in 2014-15 increased in 201415 (with the co-requisite policy), but not by as much as it did for other high schools. However, by 2015-16, college math course-taking from these 2014-15 SAILS adopters had caught up with the other high schools. When we drop from our estimation the high schools implementing SAILS in 2014-15, the estimated impact of SAILS implementation on college course-taking shrinks to 2.4 percentage points and is no longer statistically different from zero. ${ }^{10}$

\footnotetext{
${ }^{9}$ Since the policy applied to all remediation-recommended students, the "treatment on the treated" and the "intent to treat" effects were the same for the co-requisite policy.

${ }^{10}$ There are a few reasons the 2014-15 cohort of schools adopting SAILS might have had students who were less likely to enroll in college math in community college. First, students in the 2014-15 SAILS adopting high schools may have disproportionately attended community colleges that were slower to adopt co-requisite remediation for all students. Another possibility is that these students may have been disproportionately less likely to apply for and receive Tennessee Promise. Since Promise required full-time enrollment, this could have reduced these students' likelihood of taking college math in their first year relative to peers in other high schools.
} 
Both SAILS and the co-requisite policy eliminate the barriers to entry into college math. However, there are two key differences. One is that the co-requisite course may displace students' ability to take other college-level courses. Another difference is that the knowledge imparted during the SAILS course may fade between the senior year in high school and the first year in college, while the co-requisite course provides "just in time" remediation. Whether or not either of these advantages for the two approaches were substantive, they seem to have canceled each other out, as the net effect of SAILS implementation on credit accumulation under the corequisite policy was zero.

Virtually all of the reduction in college remediation expenses for the 28 percent of students shifting their remediation to high school would have represented a net cost savings, because Tennessee high school students are required to take four years of math. As long as the cost of offering a SAILS course was comparable to the cost of offering another high school math course, any reduction in instructional expenditures on co-requisite math instruction on college campuses would have represented a net cost savings.

\section{Regression Discontinuity Results}

In Table 4, we report the differences in student outcomes at the remediation threshold. We report the difference for four groups: for those in participating and non-participating high school, for the graduating classes of 2013-14 and 2015-16. While the impact estimates in Table 3 were identified based on the differential changes in outcomes when schools began implementing SAILS, the impacts in Table 4 are identified by differences in outcomes for those just above and below the threshold of 19 . They need not be the same. The comparison group in Table 3 consisted of similar students in high schools that had not yet implemented SAILS (or had implemented SAILS in some prior year), while the comparison group in Table 4 is the set of 
students with similar achievement and characteristics who just missed being recommended for remediation. We conduct both analyses to determine if our results are robust to different comparison groups. (As an additional check, Appendix Tables 6 and 8 present RD results based on multiple bandwidths for graduating seniors from 2015-16 and 2013-14, respectively.)

In SAILS-participating schools in 2013-14, students just below the remediation threshold were 27 percentage points more likely to enroll in SAILS than those just above the threshold. This is smaller than the 41-percentage-point estimate of participation in SAILS in Table 3. One possible reason is that estimates in Table 3 are for all students scoring below 19, while the results in Table 4 would apply to those with ACT scores right at the remediation cutoff.

At SAILS-participating schools in 2013-14, we estimate that those who were just below the remediation threshold were 26.9 percentage points more likely than similar students just above the threshold to take a remedial math class during their first year at a community college. However, that difference was even larger at the non-participating schools, where those below the threshold were 48.5 percentage points more likely to take a remedial class. In other words, if a school were to switch from non-participating to participating in SAILS, the difference between the two (i.e., 21.6 points) would determine the reduction in remediation at the threshold.

In non- participating schools in 2013-14, those with an ACT score just below the remediation threshold were 13.8 percentage points less likely to take a college math course and 7.8 percentage points less likely to pass a college math course during their first year in a community college. They also accumulated 1.8 fewer college credits during their first year in college.

In SAILS-participating schools, the differences at the remediation threshold were smaller and not statistically significant. Although there were 101 high schools that began offering SAILS 
in 2013-14, this represents only a quarter of all high schools in the state. As such, we cannot generate a precise estimate of the difference in parameters in the SAILS-participating and nonparticipating schools in 2013-14. Nevertheless, our results indicate that there was a difference at the remediation threshold in the proportion of students taking and passing college-level math in the schools not participating in SAILS. In the schools with SAILS, those differences were not statistically significant, suggesting that SAILS helped to reduce the negative effects of assignment to remediation.

The bottom panel of Table 4 reports analogous differences in 2015-16, after the implementation of the co-requisite policy. The difference in discontinuities suggests that entrants from SAILS schools were 13.1 percentage points less likely to take remedial math than at nonparticipating schools. Although about half as large as we estimated in Table 3, the results imply that SAILS did shift the locus of remediation from college back to high school.

However, under the co-requisite policy in 2015-16, there were no longer any statistically significant differences at the remediation threshold in the proportion of students taking or passing college-level math — either in the SAILS-participating or in the non-participating schools. This is consistent with our earlier conclusion that SAILS implementation had no effect on college math enrollment or passage once the co-requisite policy was in place. There was also no difference in credit accumulation during the first year in community college between those immediately below and above the remediation threshold of 19 .

\section{Posttest and Student Survey Results}

For the remaining results, we focus on students in the 119 SAILS-participating schools that administered the posttest and student survey in 2015-16. In Figure 4, we report the 
proportion of students in the 119 SAILS-participating high schools who actually enrolled in SAILS in 2015-16 as a function of their ACT score. To more precisely locate where the jump in participation occurs, we use the finer-grained measure of math achievement provided to us by ACT. The vertical line corresponds to an ACT score of 19. About 50 percent of those with ACT scores immediately below 19 enrolled in the SAILS program in these high schools, with a small percentage (roughly 10 percent) of those immediately above the ACT cut-off of 19 enrolled in SAILS. Those who scored a fraction of a point below the remediation cut-off were roughly 40 percentage points more likely to be enrolled in SAILS than those just above the cut- off.

To measure the causal impact of SAILS, we focus on differences in outcomes for all students above and below the remediation threshold, whether or not those students are enrolled in SAILS. We avoid comparing student participants and non-participants in SAILS schools because an individual student's enrollment decision is likely to be influenced by other factors for which we cannot control (e.g., the strength of the students' plans to complete college, a counselor's recognition that they need extra help, their school's ability to pay for computer equipment). For all these reasons and more, the individual students enrolling in the SAILS course are likely to differ from those with similar ACT scores who are not enrolled in SAILS. Rather than assume that we can control for all the relevant differences for students' enrolling in SAILS, we are more comfortable assuming that the average student, regardless of SAILS enrollment, are similar just above and below the remediation cut-off.

Nevertheless, it is still possible to estimate the impact for the average student enrolling in SAILS using the RD method. As long as being recommended for remediation only impacts a student's outcome if he or she actually enrolled in the SAILS math course, we can instrument for SAILS participation and divide any difference in outcomes at the threshold by the 41-percentage 
point difference in SAILS enrollment at the threshold. While the difference in student outcomes at the remediation threshold tells us the average effect of offering SAILS to students, dividing that difference by the difference in students enrolled in SAILS provides an estimate of the average effect on the students participating in SAILS.

As shown in Figure 5 and Table 5, it appears that the students in the SAILS classes improved no more (or less) on the ACT posttest than the students taking other math classes during their senior year. Thus, the estimated impact of the school's offering SAILS is not statistically different from zero.

Of course, the skills tested on the ACT may differ from the actual SAILS curriculum. As a result, the SAILS team identified the specific test questions which were aligned with each of the five modules included in the SAILS curriculum. We then constructed a measure of the percent of those items that students answered correctly and conducted a similar analysis, looking for evidence of differences in student performance above and below the cut-off, and did not find evidence of differences between SAILS-enrolled and non-SAILS students for those items judged to be aligned with the five modules.

It is important to remember that the comparison students - those scoring just above the remediation threshold — are also typically enrolled in a math course of some kind, since Tennessee students are required to complete four years of math in order to graduate. Other than SAILS and the other remedial math course, Bridge Math, the three most popular courses taken by students with an ACT math score of 19 in our sample of high schools were Advanced Algebra and Trigonometry (34.3 percent) ${ }^{11}$, Pre-Calculus (26.5 percent), or Statistics (21.9 percent). Approximately 10 percent of these students were enrolled in more than one math class. ${ }^{12}$ Thus,

\footnotetext{
${ }^{11}$ We also include small numbers of students who enrolled in Discrete Math and Finite Math.

${ }^{12}$ Less than 2 percent of this group seemed not to be enrolled in any math course during their senior year.
} 
the estimated impacts on the math posttest in Table 5 is not relative to the absence of a math course, but relative to the average math course that high school seniors with ACT math scores in the neighborhood of 19 typically take. ${ }^{13}$

In Table 6, we report differences in survey-based outcomes for those immediately above and below the ACT cut-off of 19. We did not find any significant differences in students' postsecondary college plans for those with ACT scores immediately above or below 19. However, we did find that students just below the cut-off of 19 were 6.6 percentage points more likely to perceive that their math course content would be useful in their careers, 10 percentage points more likely to report that they felt prepared for college math, and 6 percentage points more likely to say that they were interested in math. We also found that students just below the 19 cutoff were 8 percentage points less likely to say that their classes stayed busy, which may have been due to the self-paced instructional model used in the SAILS program. To convert these into impacts per student enrolled in SAILS, we divide by the difference in SAILS enrollment at the cut-off (41 percentage points).

In Table 7, we report differences at the remediation threshold for different subgroups of students by gender and race, and by type of high school attended. It is worth noting that the impact on student perception of being better prepared for college math was particularly large and positive for Black students (43 percentage points). Despite this perception, we did not observe an impact on posttest scores or see a disproportionate increase in college math enrollment, math passage, or accumulated credits for Black students (estimates available upon request).

\footnotetext{
${ }^{13}$ We also examined the fraction of students taking a given math course in their senior year above and below the cutoff in SAILS schools in 2015-16. Just below the cutoff for assignment to remediation, SAILS participation seems to mostly come at the expense of taking Advanced Algebra and Trigonometry, and to a lesser extent Pre-Calculus and Statistics.
} 
There was little difference in the impact of SAILS in high-poverty vs. low-poverty high schools. However, we find that SAILS was associated with a small negative difference in math achievement in the rural schools (-6.3 points on the rescaled ACT test). When divided by the percentage-point difference in students enrolling in SAILS (44.4 percentage points), this would imply about a half-point decline in ACT scores on a 36-point scale for students in rural high schools enrolling in the SAILS course.

We also calculated the percentage of students who had completed all five modules before the end of the semester or year (with 10 percent of the class time remaining.) In effect, this is a measure of students' rate of progression in the SAILS curriculum prior to the final weeks of the semester or academic year. We observed that a large share of some schools completed the modules in the final weeks and days of the semester, while students in other schools made more steady progress throughout the course. In the 25 percent of SAILS schools with the lowest completion rate by the last tenth of the semester, only 4 percent of students had completed all five modules. In the top 25 percent of SAILS schools, 77 percent of students had completed SAILS by that point. In the schools where many students completed the modules in the last days and weeks (or didn't complete SAILS at all), students immediately below the threshold were 23.7 percentage points less likely to report that their class stayed busy than the students just above the threshold. In the schools where a higher proportion of students had completed the five modules with time remaining, students were no more or less likely to report that their class stayed busy. In other words, students' perception that SAILS kept them less busy than other math classes was concentrated in schools where large numbers of students completed the program in the closing days or weeks. 


\section{CONCLUSION}

In the fall of 2013, Tennessee Governor Bill Haslam announced the "Drive to 55" campaign with the goal of nearly doubling the share of Tennesseans with a college credential from 32 percent to 55 percent by 2025 (Drive to 55, 2018). At the time the Governor made the announcement, half of Tennessee high school seniors had ACT math scores below the level considered necessary for enrolling in college-level math in the state's community colleges.

Over the last five years, the state implemented two major reforms to its remediation policies: the SAILS program allowed students to complete their math remediation during the senior year in high school, and the co-requisite remediation policy allowed students to complete their remediation concurrently with college coursework. Our results suggest that both were effective in opening the doors to college-level coursework, increasing the proportion of remediation-recommended students taking college-level math in their first year at community college by roughly 30 percentage points. However, the impacts were not additive. Once the corequisite policy was adopted, the main effect of SAILS has been to shift the locus of remediation back to high school for roughly a quarter of remediation-recommended students, but with no incremental effect on college math enrollments or credit accumulation beyond that yielded by the co-requisite policy.

In addition, our evidence suggests that SAILS is not improving students' math achievement nor boosting their likelihood of passing college math once they take the course. Of the additional students who were able to take college-level math after the introduction of SAILS, only about half passed college math. In effect, until the co-requisite policy was in place, the SAILS program opened the door to college-level math for many students and about half of the incremental entrants made it through the course successfully. The co-requisite policy opened the 
same door for the remaining students, with the same result: about half of the incremental entrants passed the math course.

In finding a small net effect of remediation, our results are consistent with the findings of earlier studies. However, our additional contribution has been to identify that both the time cost of remediation and the achievement effect of remediation are each small in magnitude. When we saw little impact on postsecondary attainment when students began completing remediation in high school, we learned that eliminating the time cost of college-campus-based remediation had little impact. Yet when we observed no difference in senior year math achievement for those enrolling in SAILS, we learned that the achievement effect was small as well.

Therefore, achieving significant improvements in the number of Tennesseans with a postsecondary credential will require identifying and clearing other barriers to college completion and not simply reducing the time cost of remediation. For instance, students may be having trouble navigating their way toward a degree, struggling to understand their course requirements or switching between majors. In a review of remedial education reform efforts in recent years, Bailey and colleagues (2016) found that programs with comprehensive, integrated, and long-lasting student supports produced the largest increases in college success outcomes. For example, programs like the City University of New York's (CUNY) Accelerated Study in Associate Programs (ASAP) that offer students comprehensive advising, tutoring, and financial support have been shown to have impacts on degree completion (Scrivener et al., 2015). Other institutions, such as Georgia State University, have been reaching out to students during the summer, allowing students to choose "meta-majors" with common course requirements during their freshman year, redesigning 
their introductory math courses, and automating parts of their advising system. ${ }^{14}$ Some of these approaches have been tested with comparison groups and have been shown to produce improvements in postsecondary access and persistence (Page \& Gehlbach, 2017), though others have not yet been evaluated (Kurzweil \& Wu, 2015).

Our findings suggest a more thorough rethinking of the content and delivery of remediation. For instance, it could be that the senior year in high school is too late to start. In a study of the effectiveness of a double-period algebra course in the 9th grade in the Chicago Public Schools, researchers found positive impacts on students' achievement in algebra (Nomi \& Allensworth, 2009). Later work found positive impacts on credits earned in high school, test scores, high school graduation, and college enrollment rates (Cortes, Goodman, \& Nomi, 2015). It is also possible that the self-paced, online course is not well-matched to the needs of lowachieving students. A growing body of work from college and high school settings has found that students with lower levels of academic preparation perform less well in online courses than with traditional instruction (Xu \& Jaggars, 2013; Bettinger, Fox, Loeb, \& Taylor, 2017; Heppen, et al., 2017). Although SAILS is not purely online (there is a teacher in the room), it is possible that the self-paced format is less effective for the students who have struggled with the material in the past. If states cannot find a model of remediation that actually increases students' success in math, the next step would be to evaluate the consequences of eliminating remediation requirements for more students.

Many students are emerging from high school without the skills traditionally expected for college-level coursework. In order to reach ambitious goals for increasing degree completion

\footnotetext{
${ }^{14}$ Other states have begun using high school grades in combination with test scores for making remediation decisions. A recent study in New York found that some of the students exempted from remediation based on a combined measure were able to pass college math (Barnett et al., 2018). These findings support earlier research with similar conclusions (Belfield \& Crosta, 2012; Scott-Clayton, 2012; Scott-Clayton, Crosta, \& Belfield, 2014).
} 
among their residents, many states are rethinking their remediation requirements. Our analysis of Tennessee's experience suggests that either allowing students to do their remediation in high school or allowing students to complete remediation alongside college coursework (co-requisite remediation) does allow students to complete a modest number of additional credits, but is unlikely to have a major effect on college completion for this group. Boosting degree completion will require a more effective model of math remediation — either in high school or college-- or the elimination of others barriers to completion, such as inadequate advising or the level of math required in gateway college courses. 


\section{REFERENCES}

Bailey, T., Bashford, J., Boatman, A., Squires, J., \& Weiss, M. (2016). IES practice guide: Strategies for postsecondary students in developmental education - A practice guide for college and university administrators, advisors, and faculty. U.S. Department of Education, Institute for Education Sciences. Retrieved from https://ies.ed.gov/ncee/wwc/PracticeGuide/23

Barnett, E.A.,Bergman, P., Kopko, E., Reddy, V., Belfield, C.R., \& Roy, S. (2018). Multiple measures placement using data analytics an implementation and early impacts report. The Center for the Analysis of Postsecondary Readiness and MDRC. Retrieved from https:/www. insidehighered.com/sites/default/server_files/media/CAPR_Multiple $\% 20$ Measures $\% 20$ Assessment $\% 20$ implementation\%20report_final $\% 20 \% 281 \% 29$.pdf

Belfield,C.R., Crosta,P.M.(2012).Predicting success in college: The importance of placementtests and high school transcripts (Working Paper No. 42). Community College Research Center: Teachers College, Columbia University. Retrieved from https://ccrc.tc.columbia.edu/me$\mathrm{dia} / \mathrm{k} 2 /$ attachments/predicting-success-placement-tests-transcripts.pdf

Bettinger, E.P., Fox, L., Loeb, S., \& Taylor, E. (2017). Virtual classrooms: How online college courses affect student success. American Economic Review, 107(9), 2855-75.

Boatman, A. \& Long, B.T. (2018). Does remediation work for all students?: How the effects of postsecondary remedial and developmental courses vary by level of academic preparation. Educational Evaluation and Policy Analysis, 40(1), 29-58.

Beginning Postsecondary Students (BPS) (2009). Authors calculations from NCES QuickStats.

Calcagno, J.C., \& Long, B.T.(2008). The impact of postsecondary remediation using a regression discontinuity approach: Addressing endogenous sorting and noncompliance (NBER Working Paper. No. 14194). Cambridge, MA: National Bureau of Economic Research.

Complete College America. (2012). Remediation: Higher education's bridge to nowhere. Retrieved from https://postsecondary.gatesfoundation.org/report/remediation-higher-educations-bridge-to-nowhere/

Cortes, K.E., Goodman, J.S., \& Nomi, T.(2015). Intensive math instruction and educational attainment: Long-run impacts of double-dose algebra. Journal of Human Resources, 50(1), 108-158.

Drive to 55 Alliance (2018). Home. Retrieved from http://driveto55.org/

Educause. (2014, July 14). Chattanooga State Community College: U Do the Math Program. Retrieved from https://library.educause.edu/ /media/files/library/2014/7/ngp1403-pdf.pdf

Heppen, J. B., Sorensen, N., Allensworth, E., Walters, K., Rickles, J., Taylor, S. S., \& Michelman, V.(2017). The struggle to pass algebra: Online vs. face-to-face credit recovery for at-risk urban students. Journal of Research on Educational Effectiveness, 10(2), 272-296.

Higher Education for Higher Standards (2016). Precollege interventions help increase college readiness, reduce remediation. Retrieved from http:/higheredforhigherstandards.org/scalingsails/ 
IMPAQ International. (2016, June). SAILS Implementation Study: Final report. Unpublished manuscript.

Kurlaender, M., Lusher, L., \& Case, M. (2017). Evaluating remediation reforms at the California State University. Presentation. Retrieved fromhttps:/edpolicyinca.org/sites/default/files/ Kurlaender\%20PACE\%20Presentation\%20Slides\%20April\%2021\%202017.pdf

Kurzweil,M., \& Wu,D.D.(2015). Building a pathway to student success at Georgie State University (Case Study). New York: ITHAKA S+R.

Logue, A. W., Douglas, D., \& Watanabe-Rose, M. (2019). Corequisite Mathematics Remediation: Results Over Time and in Different Contexts. Educational Evaluation and Policy Analysis.

Lumina Foundation. (2018). A Stronger Nation: Learning beyond high school builds American talent. Indianapolis, IN: Lumina Foundation. http://strongernation.luminafoundation.org/report/2019/\#nation

Martorell, P., \& McFarlin, I., Jr. (2011). Help or hindrance? The effects of college remediation on academic and labor market outcomes. The Review of Economics and Statistics, 93(2), 436454.

McCrary, J. (2008). Manipulation of the running variable in the regression discontinuity design: A density test. Journal of Econometrics, 142(2), 698-714.

Nomi, T., \& Allensworth, E. (2009). Double-dose algebra as an alternative strategy to remediation:Effects on students' academic outcomes. Journal of Research on EducationalEffectiveness, 2(2), 111-148.

Page, L., \& Gehlbach, H. (2017). How an artificially intelligent virtual assistant helps students navigate the road to college. AERA Open,3(4), 1-12.https://doi. org/10.1177/2332858417749220

Scott-Clayton, J., Crosta, P.M., \& Belfield, C.R. (2014). Improving the targeting of treatment: Evidence from college remediation. Educational Evaluation and Policy Analysis, 36(3), 371393. http://epa. sagepub.com/content/early/2014/01/28/0162373713517935

Scott-Clayton, J., \& Rodriguez, O. (2012). Development, discouragement, or diversion? New evidence on the effects of college remediation. National Bureau ofEconomic Research(Working Paper No. 18328). Cambridge, MA: NBER.

Scrivener, S., Gupta, H., Weiss, M.J., Cohen, B., Scott Cormier, M., \& Brathwaite, J. (2018). Becoming college-ready: Early Findings from a CUNY Start Evaluation. Retrieved from https://www.mdrc.org/sites/default/files/CUNY_START_Interim_Report_FINAL_0. pdf

Skomsvold, P. (2014). Profile of undergraduate students: 2011-12 (NCES 2015-167). National Center for Education Statistics, Institute of Education Sciences, U.S. Department of Education. Washington, DC. 
Tennessee Board of Regents. (2016). Seamless Alignment and Integrated Learning Support (SAILS). Information Sheet. Retrieved from https://www.tbr.edu/sites/tbr.edu/files/ SAILSInfoSheet.pdf

Tennessee Higher Education Commission (2013). Seamless Alignment and Integrated Learning Support: Program overview and update. Presentation. Retrieved from https://www.insidehighered.com/sites/default/server_files/files/SAILS\%20THEC\%20Template.pdf

Tennessee Higher Education Commission. (2014). 2013-2014 Tennessee Higher Education Commission Fact Book. Nashville, Tennessee: Author.

Tennessee Higher Education Commission. (2018). 2017-2018 Tennessee Higher Education Commission Fact Book. Nashville, Tennessee: Author.

Tennessee Higher Education Commission \& Student Assistance Corporation. (2018). TN Promise Annual Report. Nashville, Tennessee: Author.

Xu, D., \& Jaggars, S.S.(2013). The impact of online learning on students' course outcomes: Evidence from a large community and technical college system. Economics of Education Review, 37(C), 46-57. 
Figure 1. Postsecondary Enrollment by Institutions' TN Promise Eligibility

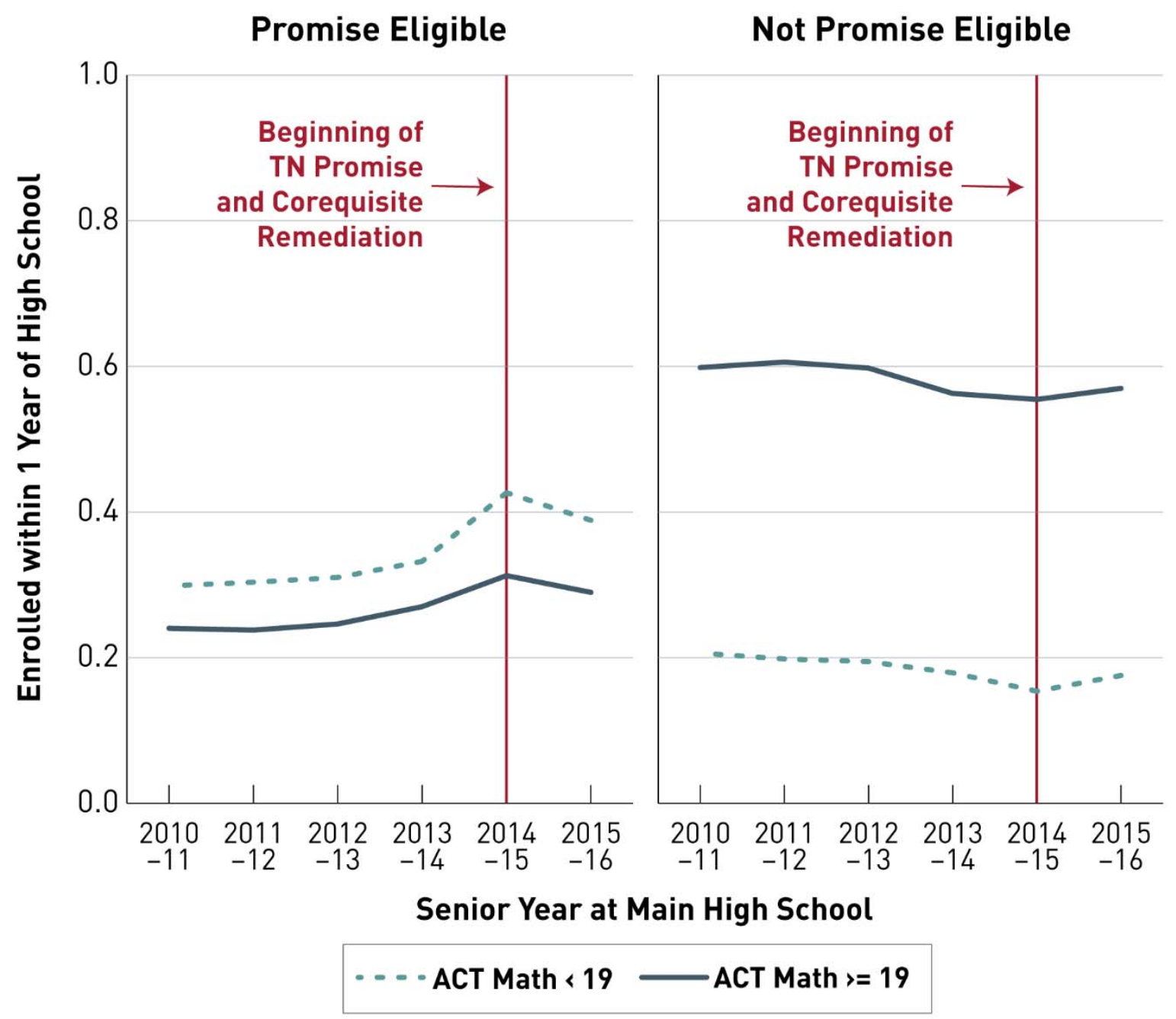

Notes: This figure presents the proportion of Tennessee high school seniors who enrolled in postsecondary institutions within 1 year of high school, by junior-year ACT math score and TN Promise eligibility of the institution. "Promise-eligible" institutions include Tennessee community colleges, Tennessee Colleges of Applied Technology, two public 4-year institutions that offered associate's degrees (Austin Peay State University and Tennessee State University), and several private institutions that offered associate's degrees (e.g., Bryan College and Cumberland University). 
Figure 2. Postsecondary Progress for Community College Entrants
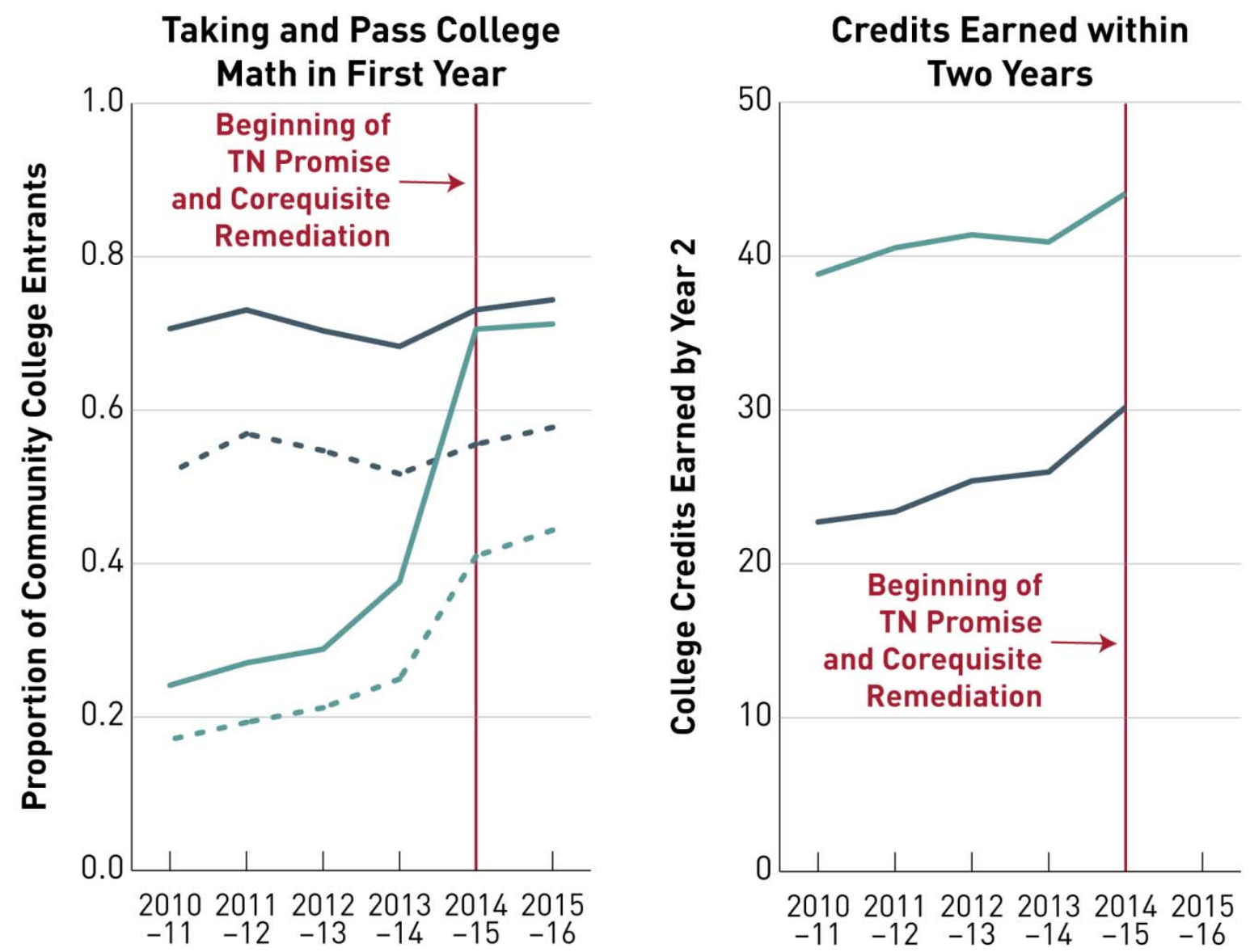

Senior Year at Main High School
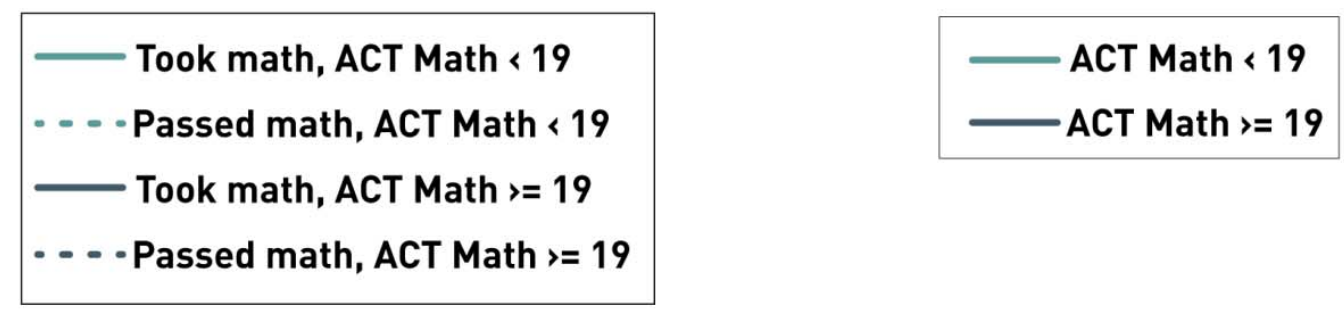

Notes: This figure presents descriptive outcomes for high school seniors who enrolled in a Tennessee community college within 1 year after high school, by junior-year ACT math score. The left panel shows the overall proportion of these community college entrants who enrolled in and passed college-level math within 1 year after high school. The right panel shows the number of credits these community college entrants earned within 2 years after high school. Credits earned exclude remedial math courses, but may include remedial reading and writing courses due to data limitations. 
Figure 3. Rates of College Math-Taking, by SAILS Cohort (ACT<19)

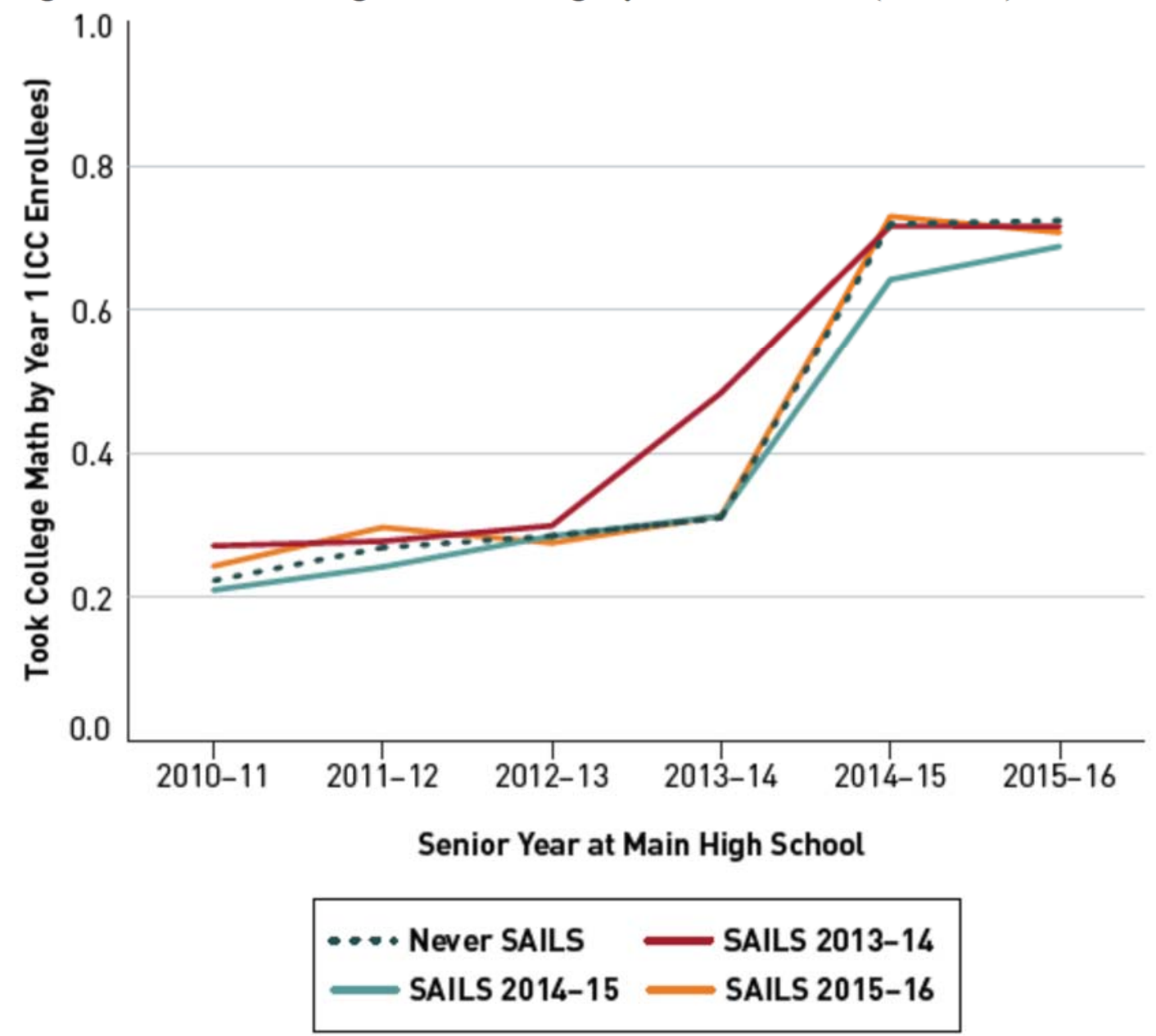

Notes: This figure plots the percentage of community college enrollees who took college math within year one after high school, grouping students by when their high school adopted schools (if ever). The x-axis represents students' senior year in high school. Students who are seniors in 2014-15 would have experienced co-requisite remediation when they arrived at community college in Fall 2015. 
Figure 4. Proportion of Students Taking SAILS by Rescaled ACT Score

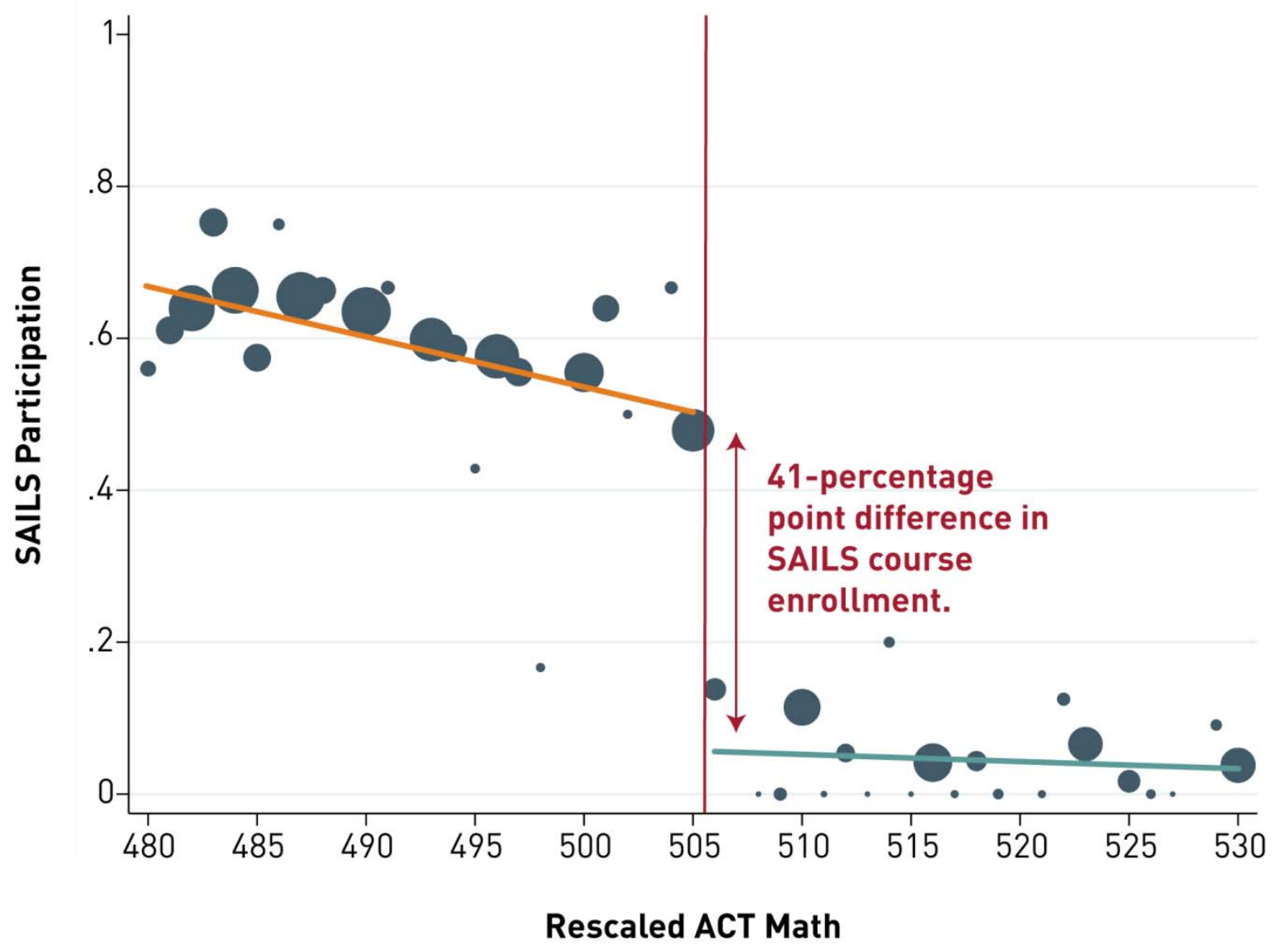

Notes: Figure depicts SAILS participation among seniors at high schools that offered SAILS in 2015-16, with a focus on students near the threshold for math remediation based on their junior-year pre-test. Rescaled scores refer to the finer-grained junior-year ACT math scores that ranged from 333 to 680. A coarse score of 19 on the ACT math section corresponded to a rescaled score of 506, as indicated with a vertical red line. 
Figure 5. Score on Posttest by Pretest Score

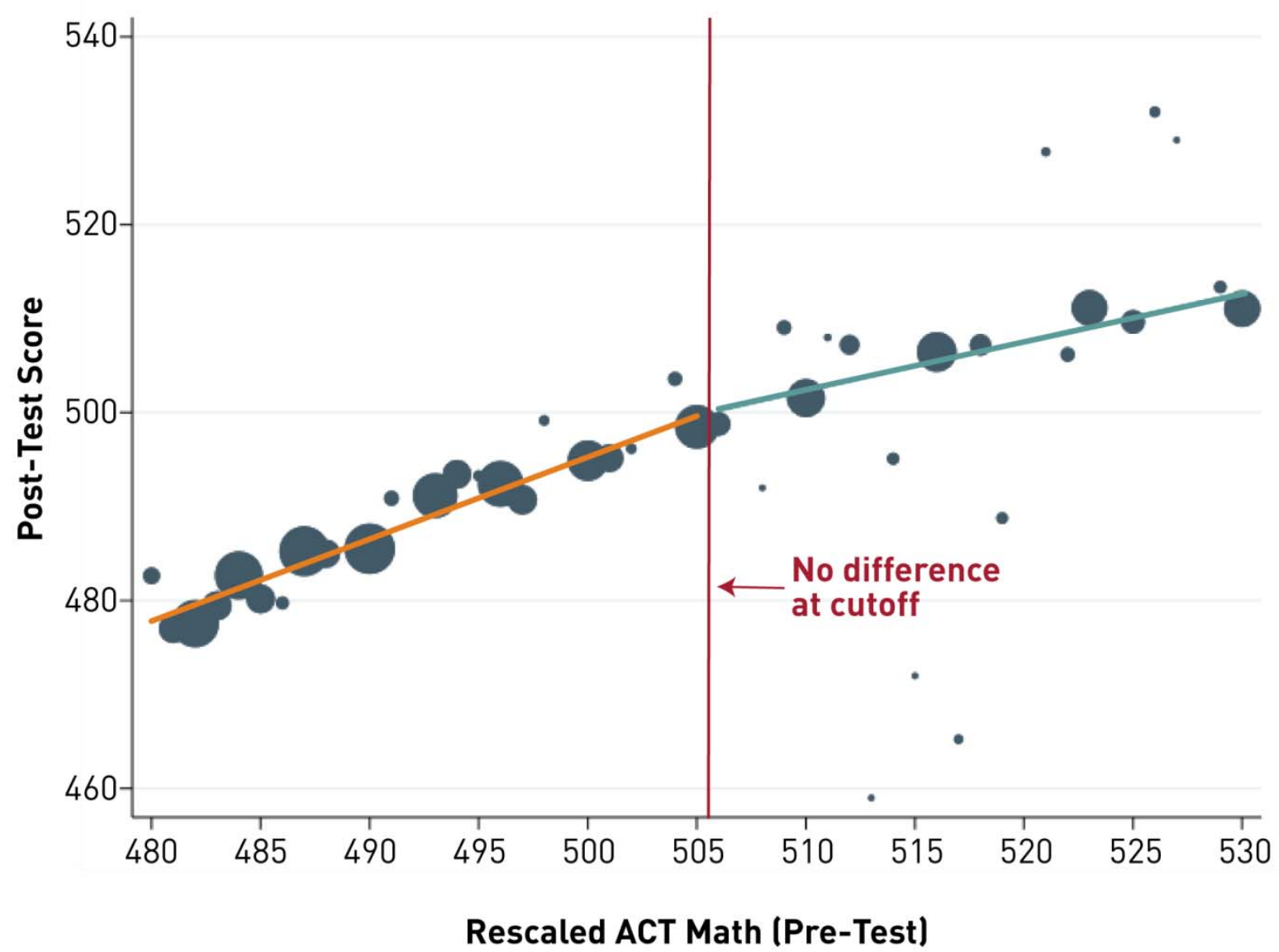

Notes: Figure depicts ACT math post-test scores for students at high schools that offered SAILS in 2015-16, with a focus on students whose ACT math pre-test scores were near the threshold for math remediation. Rescaled scores refer to the finer-grained junior-year ACT math scores that ranged from 333 to 680 . A coarse score of 19 on the ACT math section corresponded to a rescaled score of 506, as indicated with a vertical red line. 
Table 1. Characteristics of high schools by first year of SAILS implementation

\begin{tabular}{|c|c|c|c|c|c|}
\hline \multirow[b]{2}{*}{ Student characteristics } & \multicolumn{3}{|c|}{ Year of SAILS implementation } & \multicolumn{2}{|c|}{ As of 2015-16 } \\
\hline & 2013-14 & $2014-15$ & $2015-16$ & $\begin{array}{c}\text { Ever } \\
\text { SAILS }\end{array}$ & $\begin{array}{l}\text { Never } \\
\text { SAILS }\end{array}$ \\
\hline Male & 0.51 & 0.50 & 0.51 & 0.51 & 0.51 \\
\hline White & 0.80 & 0.67 & 0.70 & 0.75 & 0.65 \\
\hline Black & 0.16 & 0.30 & 0.26 & 0.22 & 0.30 \\
\hline Hispanic & 0.07 & 0.05 & 0.06 & 0.06 & 0.06 \\
\hline English language learner & 0.07 & 0.04 & 0.05 & 0.06 & 0.06 \\
\hline IEP & 0.13 & 0.12 & 0.11 & 0.12 & 0.12 \\
\hline Days absent & 12.76 & 12.89 & 10.62 & 12.40 & 10.61 \\
\hline Graduate high school & 0.92 & 0.89 & 0.86 & 0.90 & 0.88 \\
\hline Urban high school & 0.31 & 0.26 & 0.34 & 0.30 & 0.42 \\
\hline Suburban/town high school & 0.33 & 0.42 & 0.30 & 0.34 & 0.41 \\
\hline Rural high school & 0.36 & 0.32 & 0.36 & 0.36 & 0.17 \\
\hline Took senior math & 0.90 & 0.89 & 0.87 & 0.89 & 0.88 \\
\hline Took SAILS & 0.29 & 0.28 & 0.16 & 0.26 & 0.00 \\
\hline Have ACT math (rescaled) & 0.68 & 0.69 & 0.71 & 0.69 & 0.70 \\
\hline ACT math & 18.37 & 18.06 & 18.47 & 18.30 & 19.23 \\
\hline ACT math $<19$ & 0.50 & 0.53 & 0.49 & 0.51 & 0.46 \\
\hline 12th grade students $(\mathrm{N})$ & 24,511 & 11,311 & 12,224 & 49,622 & 24,115 \\
\hline $\begin{array}{l}\text { Schools beginning SAILS } \\
\text { (N) }\end{array}$ & 101 & 66 & 58 & & \\
\hline $\begin{array}{l}\text { Total schools using SAILS } \\
(\mathrm{N})\end{array}$ & 120 & 180 & 236 & 245 & 166 \\
\hline
\end{tabular}

Notes: The table reports characteristics for 2015-16 seniors in schools that had started SAILS in 2013-14, 2014-15 or 2015-16. The label, "Ever SAILS," refers to schools that ever participated in SAILS between 2013-14 and 2015-16. Rescaled scores refer to the finer-grained ACT scores ranging from 333 to 680 . 
Table 2. Comparing the posttest sample to the full sample of eligible schools (2015-16)

\begin{tabular}{|c|c|c|c|c|}
\hline & \multirow{2}{*}{$\begin{array}{c}\begin{array}{c}\text { Eligible } \\
\text { Schools } \\
(\mathrm{n}==187)\end{array} \\
\begin{array}{c}\text { All } \\
\text { students }\end{array}\end{array}$} & \multicolumn{3}{|c|}{$\begin{array}{l}\text { Post-Test Participating Schools } \\
\qquad(\mathrm{n}==119) \\
\end{array}$} \\
\hline & & $\begin{array}{l}\text { All } \\
\text { students }\end{array}$ & $\begin{array}{c}\text { Students in } \\
\text { Targeted } \\
\text { Classes }\end{array}$ & $\begin{array}{c}\text { Students } \\
\text { with Post- } \\
\text { Tests } \\
\end{array}$ \\
\hline & $(1)$ & $(2)$ & (3) & (4) \\
\hline Male & 0.51 & 0.50 & 0.49 & 0.49 \\
\hline White & 0.76 & 0.75 & 0.75 & 0.78 \\
\hline Black & 0.21 & 0.22 & 0.22 & 0.19 \\
\hline Hispanic & 0.06 & 0.06 & 0.07 & 0.06 \\
\hline English language learner & 0.06 & 0.06 & 0.06 & 0.05 \\
\hline IEP & 0.12 & 0.12 & 0.06 & 0.05 \\
\hline Days absent & 12.98 & 11.97 & 12.58 & 10.73 \\
\hline Graduate high school & 0.91 & 0.93 & 0.96 & 0.99 \\
\hline Urban high school & 0.29 & 0.28 & 0.28 & 0.25 \\
\hline Suburban/town high school & 0.36 & 0.36 & 0.37 & 0.38 \\
\hline Rural high school & 0.36 & 0.35 & 0.35 & 0.37 \\
\hline Took senior math & 0.90 & 0.92 & 0.99 & 1.00 \\
\hline Took SAILS & 0.30 & 0.33 & 0.43 & 0.46 \\
\hline Has ACT math & 0.78 & 0.80 & 0.86 & 0.89 \\
\hline ACT math & 18.24 & 18.13 & 17.54 & 17.79 \\
\hline ACT math $<19$ & 0.52 & 0.54 & 0.63 & 0.63 \\
\hline Have ACT math (rescaled) & 0.69 & 0.75 & 0.83 & 0.89 \\
\hline ACT math (rescaled) & 499.40 & 499.05 & 494.74 & 497.72 \\
\hline 12th grade students $(\mathrm{N})$ & 37398 & 22317 & 15808 & 9560 \\
\hline
\end{tabular}

Notes: The eligible schools are the 187 schools which were in their second or third year of SAILS implementation in 2015-16. The eligible, participating schools are the subset of 119 schools which agreed to participate in the posttest and student survey. Column 3 limits the sample to those students which were in classes that administered the posttest. Column 4 limits this sample further to those students which actually took the posttest. Rescaled scores refer to the finer-grained ACT scores ranging from 333 to 680. 
Dependent Variable

\section{A. High School and College Enrollment}

SAILS participant

High School (HS) Graduate

Enrolled in any college by spring of 1 st year after HS

Enrolled in 2 Yr college by spring of 1 st year after HS

Enrolled in 4 Yr college by spring of 1 st year after HS

B. Postsecondary Outcomes for CC Enrollees

Took remedial math by spring of 1 st year

Took remedial math by spring of 2 nd year

Took college math by spring of 1 st year

Took college math by spring of 2 nd year

Pass college math by spring of 1 st year

Pass college math by spring of 2 nd year

Total credits earned by spring of 1 st year

Total credits earned by spring of 2 nd year

Return for 2 nd year of college

Earned associate's degree by 2nd year

Earned certificate by 2 nd year

\section{Mean for \\ Non- \\ SAILS \\ Schools}

0.00

0.92

0.52

0.27

0.26
SAILS Impact:

\begin{tabular}{|c|c|}
\hline Under & Under \\
\hline Pre-requisite & Co-Requisite \\
\hline Remediation & Remediation \\
\hline
\end{tabular}

$0.407 * * *$

$(0.024)$

$0.409 * * *$

198,091

(0.019)

(0.010)

(0.009)
$-0.000$

$-0.001$

(0.004)

(0.005)

0.017 *

$(0.010)$

0.012

(0.009)

0.004

(0.006)

198,091

198,091

198,091

198,091

(0.007)
$-0.284 * * *$

(0.018)

(0.023)

0.72

$-0.299 * * *$

(0.024)

$-0.322 * * *$

(0.022)

0.45

$0.140 * * *$

(0.019)

$-0.035 * * *$

(0.013)

0.53

$0.066 * * *$

(0.017)

0.30

$0.063 * * *$

(0.014)

$-0.055 * * *$

(0.014)

$-0.054 * * *$

(0.012)

0.37

0.021

(0.014)

$-0.062 * * *$

(0.014)

$16.33 \quad 0.965 * * *$

(0.274)

0.210

(0.298)

25.04

$2.210 * * *$

(0.548)

0.62

$-0.017$

(0.013)

0.04

0.002

(0.006)

0.04

0.008

0.736

(0.707)

$-0.012$

(0.014)

$-0.003$

(0.006)

$-0.003$

34,339

39,985

39,985

(0.008)

39,985

(0.007)

Notes: Impact estimates for each outcome are coefficients on indicators for attending a SAILS high school under pre-requisite remediation (those graduating in 2013-14) under co-requisite remediation (those graduating after 2013-14), the reference category being those attending non-SAILS schools in the same year. The sample is limited to public high school seniors between 2010-11 and 2015-16 with junior year ACT math scores below 19. All specifications include h.s. fixed effects and indicators for race, ethnicity, and sex. The sample for the lower panel is limited to students enrolling in a Tennessee community college within 1 year after high school, regardless of degree intention. Heteroskedastic-robust standard errors are clustered by high school and are reported in parentheses $(* \mathrm{p}<.10 ; * * \mathrm{p}<.05 ; * * * \mathrm{p}<.01)$. 


\begin{tabular}{lccccc} 
Dependent Variable & \multicolumn{2}{c}{$\begin{array}{c}\text { Control } \\
\text { mean }\end{array}$} & Discontinuity & $\begin{array}{c}\text { Control } \\
\text { mean }\end{array}$ & $\begin{array}{c}\text { Difference in } \\
\text { Discontinuity }\end{array}$ \\
\hline SAILS participant & $2013-14$ High School Seniors & & & \\
& $0.271^{* * *}$ & 0.14 & 0.000 & 0.00 & $0.271^{* * *}$ \\
Took Bridge course & $(0.035)$ & & $(0.000)$ & & $(0.035)$ \\
& -0.030 & 0.20 & $0.162^{* * *}$ & 0.30 & $-0.192^{* * *}$ \\
& $(0.027)$ & & $(0.020)$ & & $(0.034)$ \\
Outcomes for TN CC Enrollees: & {$[\mathrm{N}=11,259]$} & & {$[\mathrm{N}=23,287]$} & & \\
Took remedial math by spring of 1st year & $0.269^{* * *}$ & 0.03 & $0.485^{* * *}$ & 0.04 & $-0.216^{* * *}$ \\
& $(0.035)$ & & $(0.025)$ & & $(0.043)$ \\
Took math by spring of 1st year & -0.062 & 0.69 & $-0.138^{* * *}$ & 0.67 & 0.076 \\
& $(0.049)$ & & $(0.033)$ & & $(0.059)$ \\
Pass math by spring of 1st year & 0.008 & 0.47 & $-0.078^{* *}$ & 0.49 & 0.086 \\
& $(0.044)$ & & $(0.036)$ & & $(0.057)$ \\
Total credits earned by spring of 1st year & {$[\mathrm{N}=3,206]$} & & {$[\mathrm{N}=5,232]$} & & 1.893 \\
& 0.096 & 22.31 & $-1.797^{* *}$ & 21.84 & $(1.349)$
\end{tabular}

\section{5-16 High School Seniors}

SAILS Participation

Took Bridge course

Outcomes for TN CC Enrollees:

Took remedial math by spring of 1 st year

Took math by spring of 1 st year

Pass math by spring of 1 st year

Total credits earned by spring of 1 st year

$$
0.340 * * *
$$$$
\text { (0.024) }
$$$$
-0.007
$$$$
\text { (0.017) }
$$

$[\mathrm{N}=12,073]$

$0.146^{* * *} \quad 0.02$

(0.020)

[3939]

0.050

(0.037)

[3939]

$$
\begin{aligned}
& 0.080^{*} \\
& (0.041)
\end{aligned}
$$

[3939]

$-0.288$

(0.900)

[3440]
0.07

0.11

0.02

0.72

0.50

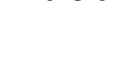

24.78

$\begin{array}{cc}0.001 & 0.00 \\ (0.002) & \\ 0.093^{* * *} & 0.20 \\ (0.026) & \\ {[\mathrm{N}=5,806]} & \\ 0.277^{* * *} & 0.01 \\ (0.033) & \\ {[1553]} & \end{array}$

0.00

$0.339 * * *$

$(0.024)$ $-0.100 * * *$ $(0.031)$ $-0.052$ 0.76

$0.102 *$ (0.054) [1553] $-0.011$ (0.063) [1553]

0.775 24.05 (1.220) [1388]
(0.065)

0.091 (0.075)

$-1.063$

(1.516)

Notes: We assume a linear relationship to the running variable above and below the cut-off. ACT scores are integer values for 2013-14 and rescaled score with within-integer values in 2015-16. All regressions also include high school fixed effects and indicators for race, ethnicity, and sex. We use a bandwidth of 4 integer points in 2013-14 and 25 rescaled ACT points in 2015-16. We provide estimates for a variety of alternative bandwidths in the Appendix Tables A6 and A8. Control means are calculated for students within 10 points above the cut-off on the rescaled measure or a single point using the integer ACT measure. Heteroskedasty-robust standard errors are clustered by high school and included in parentheses $(* p<0.10 ; * * p<0.05 ; * * * p<0.01)$. 


\begin{tabular}{lcccc}
\hline & & & \multicolumn{2}{c}{ Control } \\
mean
\end{tabular}

Notes: For the outcome in each row, we report the discontinuity at the remediation cut-off of 19 , assuming a linear relationship between the outcome and the rescaled ACT score (the running variable) and allowing for different slopes above and below the cut-off. Each specification also includes high school fixed effects and demographic controls for race, ethnicity, and sex. We use a bandwidth of +/25 points on the fine-grained, rescaled ACT (whose total range runs from 333 to 680) for our main specification, but also include a narrower (+/- 15 points) and a wider bandwidth (+/- 35 points). The optimal bandwidths suggested by Calonico, Cattaneo, and Titiunik (2014) range from 22 to 27 for all outcomes. Posttest Math \% Correct indicates the \% correct on the posttest, as opposed to the scale score on the posttest. SAILS-aligned Posttest \% Correct indicates the \% correct on the items on the posttest that the SAILS staff indicated as aligned with the SAILS curriculum. Sample includes only high school seniors in the schools that participated in the posttest and student surveys in the 2015-16 school year. Control means are the mean outcomes for students within 10 points above the cutoff. Standard errors are clustered at the high school level. $(* p<0.10 ; * * p<0.05 ; * * * p<0.01)$. 


\begin{tabular}{|c|c|c|c|c|}
\hline & BW25 & BW15 & BW35 & $\begin{array}{c}\text { Control } \\
\text { mean }\end{array}$ \\
\hline \multirow[t]{3}{*}{ Intend to attend college } & -0.001 & -0.010 & 0.013 & 0.86 \\
\hline & $(0.028)$ & $(0.039)$ & $(0.025)$ & \\
\hline & {$[3699]$} & {$[1765]$} & {$[5847]$} & \\
\hline \multirow[t]{3}{*}{ Plan to attend 2-year } & -0.040 & 0.002 & -0.030 & 0.36 \\
\hline & $(0.035)$ & $(0.060)$ & $(0.029)$ & \\
\hline & [3699] & [1763] & {$[5845]$} & \\
\hline \multirow[t]{3}{*}{ Plan to attend 4-year } & 0.002 & -0.025 & 0.012 & 0.51 \\
\hline & $(0.039)$ & $(0.065)$ & $(0.032)$ & \\
\hline & [3699] & [1763] & {$[5845]$} & \\
\hline \multirow[t]{3}{*}{ Highest expected attainment - AA or certificate } & -0.011 & -0.034 & -0.019 & 0.18 \\
\hline & $(0.033)$ & $(0.054)$ & $(0.033)$ & \\
\hline & [3694] & {$[1762]$} & {$[5840]$} & \\
\hline \multirow[t]{3}{*}{ Highest expected attainment - BA/BS or Higher } & 0.011 & 0.034 & 0.019 & 0.82 \\
\hline & $(0.033)$ & $(0.054)$ & $(0.033)$ & \\
\hline & {$[3694]$} & {$[1762]$} & {$[5840]$} & \\
\hline \multirow[t]{3}{*}{ Course content useful in career } & $0.065 *$ & $0.105^{*}$ & $0.062 *$ & 0.42 \\
\hline & $(0.037)$ & $(0.054)$ & $(0.032)$ & \\
\hline & {$[3719]$} & [1769] & [5884] & \\
\hline \multirow[t]{3}{*}{ Better prepared for college math } & $0.102 * *$ & 0.093 & $0.088 * *$ & 0.58 \\
\hline & $(0.040)$ & $(0.067)$ & $(0.034)$ & \\
\hline & {$[3721]$} & [1769] & [5883] & \\
\hline \multirow[t]{3}{*}{ More interested in math } & $0.059 * *$ & 0.024 & $0.040 *$ & 0.20 \\
\hline & $(0.030)$ & $(0.051)$ & $(0.023)$ & \\
\hline & {$[3715]$} & {$[1768]$} & {$[5873]$} & \\
\hline \multirow[t]{3}{*}{ Class stays busy } & $-0.080 * *$ & $-0.178 * * *$ & $-0.085 * * *$ & 0.74 \\
\hline & $(0.040)$ & $(0.057)$ & $(0.032)$ & \\
\hline & [3714] & {$[1766]$} & [5871] & \\
\hline
\end{tabular}

Notes: For the outcome in each row, we report the discontinuity at the remediation cut-off of 19, assuming a linear relationship between the outcome and the rescaled ACT score (the running variable) and allowing for different slopes above and below the cut-off. Each specification also includes high school fixed effects and demographic controls for race, ethnicity, and sex. The sample includes only high school seniors in the schools that participated in the posttest and student surveys in the 2015-16 school year. Optimal bandwidths from Calonico, Cattaneo, and Titiunik (2014) range from 16 to 34 depending on the outcome. We use a bandwidth of $+/-25$ points on the fine-grained, rescaled ACT (whose total range runs from 333 to 680) for our main specification, but also include a narrower ( $+/-15$ points) and a wider bandwidth (+/- 35 points). Sample sizes (in brackets) vary slightly across outcomes due to differential response rates to some questions. Control means are the mean outcomes for students within 10 points above the cutoff. Standard errors are clustered at the school level $(* \mathrm{p}<0.10 ; * * \mathrm{p}<0.05 ; * * * \mathrm{p}<0.01)$. 


\begin{tabular}{|c|c|c|c|c|c|c|}
\hline & \multirow[b]{2}{*}{$\begin{array}{c}\text { SAILS } \\
\text { participation }\end{array}$} & \multirow[b]{2}{*}{$\begin{array}{c}\text { Post-test } \\
\text { math score }\end{array}$} & \multicolumn{4}{|c|}{ Student Survey } \\
\hline & & & $\begin{array}{c}\text { Course } \\
\text { content } \\
\text { useful in } \\
\text { career }\end{array}$ & $\begin{array}{l}\text { Better } \\
\text { prepared for } \\
\text { college math }\end{array}$ & $\begin{array}{c}\text { More } \\
\text { interested in } \\
\text { math }\end{array}$ & $\begin{array}{c}\text { Class stays } \\
\text { busy }\end{array}$ \\
\hline \multicolumn{7}{|l|}{ Student-level } \\
\hline \multirow[t]{3}{*}{ Female } & $0.409^{* * *}$ & 1.157 & 0.056 & $0.126^{* *}$ & 0.068 & -0.080 \\
\hline & $(0.047)$ & $(3.446)$ & $(0.054)$ & $(0.061)$ & $(0.046)$ & $(0.056)$ \\
\hline & [2057] & [2057] & [1996] & [1996] & [1994] & [1992] \\
\hline \multirow[t]{3}{*}{ Male } & $0.403 * * *$ & -1.185 & 0.069 & $0.089 *$ & 0.059 & -0.081 \\
\hline & $(0.051)$ & $(3.181)$ & $(0.058)$ & $(0.052)$ & $(0.047)$ & $(0.053)$ \\
\hline & [1788] & {$[1788]$} & {$[1723]$} & {$[1725]$} & [1721] & [1722] \\
\hline \multirow[t]{3}{*}{ Black } & $0.395 * * *$ & 1.771 & 0.196 & $0.433 * * *$ & 0.170 & -0.183 \\
\hline & $(0.073)$ & $(5.977)$ & $(0.122)$ & $(0.133)$ & $(0.107)$ & $(0.119)$ \\
\hline & [684] & {$[684]$} & {$[651]$} & [651] & [649] & {$[650]$} \\
\hline \multirow[t]{3}{*}{ White } & $0.400 * * *$ & -0.553 & $0.081^{*}$ & $0.077^{*}$ & 0.052 & -0.051 \\
\hline & $(0.038)$ & $(2.511)$ & $(0.041)$ & $(0.042)$ & $(0.034)$ & $(0.041)$ \\
\hline & {$[3072]$} & {$[3072]$} & [2982] & [2984] & [2980] & [2978] \\
\hline \multicolumn{7}{|l|}{ School-level } \\
\hline \multirow[t]{3}{*}{ Rural high school } & $0.444 * * *$ & $-6.317 * *$ & $0.100^{*}$ & $0.103^{*}$ & 0.028 & 0.016 \\
\hline & $(0.061)$ & $(3.032)$ & $(0.058)$ & $(0.055)$ & $(0.052)$ & $(0.056)$ \\
\hline & {$[1550]$} & {$[1550]$} & {$[1487]$} & [1490] & [1486] & [1487] \\
\hline \multirow{3}{*}{ Non-Rural high school } & $0.391 * * *$ & 4.533 & 0.043 & $0.109^{*}$ & $0.082^{* *}$ & $-0.145^{* * *}$ \\
\hline & $(0.046)$ & $(3.077)$ & $(0.050)$ & $(0.057)$ & $(0.036)$ & $(0.053)$ \\
\hline & [2295] & [2295] & [2232] & [2231] & [2229] & [2227] \\
\hline \multirow{3}{*}{$\begin{array}{l}\text { High Poverty School: } \\
>=65 \% \text { School FRPL }\end{array}$} & $0.429 * * *$ & 1.062 & 0.109 & 0.162 & 0.112 & -0.053 \\
\hline & $(0.075)$ & $(4.776)$ & $(0.079)$ & $(0.096)$ & $(0.066)$ & $(0.105)$ \\
\hline & [884] & [884] & [840] & [843] & [839] & [842] \\
\hline \multirow{3}{*}{$\begin{array}{l}\text { Low Poverty School: } \\
<=35 \% \text { School FRPL }\end{array}$} & $0.422 * * *$ & -6.895 & -0.024 & 0.079 & 0.061 & -0.093 \\
\hline & $(0.068)$ & $(5.564)$ & $(0.057)$ & $(0.106)$ & $(0.056)$ & $(0.097)$ \\
\hline & [599] & [599] & [583] & [583] & [583] & [582] \\
\hline \multirow{3}{*}{$\begin{array}{l}\% \text { Complete at } 90 \% \\
\text { through the course: } \mathrm{Q} 1\end{array}$} & $0.285^{* * *}$ & -0.256 & 0.045 & 0.161 & 0.099 & $-0.237 * *$ \\
\hline & $(0.089)$ & (4.917) & $(0.074)$ & $(0.126)$ & $(0.087)$ & $(0.104)$ \\
\hline & {$[614]$} & [614] & {$[583]$} & [583] & [582] & [581] \\
\hline \multirow{3}{*}{$\begin{array}{l}\% \text { Complete at } 90 \% \\
\text { through the course: } \mathrm{Q} 4\end{array}$} & $0.344 * * *$ & 1.673 & 0.123 & 0.087 & 0.025 & 0.047 \\
\hline & $(0.075)$ & $(3.946)$ & $(0.075)$ & $(0.067)$ & $(0.057)$ & $(0.062)$ \\
\hline & [1077] & [1077] & {$[1060]$} & [1059] & [1058] & [1058] \\
\hline
\end{tabular}

Notes: Each estimate comes from a local linear model that regresses the outcome of interest on an indicator for a student having a rescaled ACT score that is equivalent to scoring below 19, a rescaled ACT math score centered at the threshold, and an interaction of the two. All regressions include high school fixed effects and demographic controls for race, ethnicity, and sex. Sample is limited to high school seniors in the 119 schools that participated in the post-test and student surveys in 2015-16, who took the post-test/student survey, and are in the demographic subgroup denoted in column 1. Sample sizes (in brackets) vary slightly across outcomes due to response rates. All regressions use a bandwidth of $+/-25$ points. Control means are the the mean outcomes for students within 10 points above the cutoff. Heteroskedastic robust standard errors are clustered by high school and included in parentheses $\left({ }^{*} \mathrm{p}<0.10 ;{ }^{* *} \mathrm{p}<0.05\right.$; $* * * \mathrm{p}<0.001)$. 